\title{
GÁPEL ENDRE
}

\section{FEJEZETEK, ARCKÉPVÁZLATOK A DEAC LABDARÚGÓ SZAKOSZTÁLYÁNAK TÖRTÉNETÉBÖL}

\begin{abstract}
Chapters and Sketches of Portraits pertaining to the History of the Soccer Division of the DeBReCEN UNIVERSITY ATHLETIC ClUb. The Athletic Club of the University of Debrecen (DEAC) was established on the first day of August, 1919, by the University's managers, professors and various renowned public figures with the primary objective of ensuring sporting opportunities and facilities for the student body, the educators and other employees of the University. The soccer club of DEAC achieved the peak of its development in the 1960s and 1970s, when the University's team managed to qualify to play in the second division of the national football league (NB II). In those days the team attracted large crowds. Each team member was a student and they also were successful as students. Besides offering a survey of tangible successes in football, the present discussion also highlights the subsequent careers of the respective members of the team. A number of these successful soccer players also achieved outstanding professional careers, some of them became professors, well-known medical doctors, school pricipals, and sports managers of international rank The survey also introduces those university managers who supported and promoted the quality sporting activities of the students. The essay is a much-needed elaboration adding substantially to a better understanding of the scope, the past and present of the University of Debrecen. It is both a history of sport and the history of an institution.
\end{abstract}

\section{A hírnevet kibontakoztató, megalapozó idöszak és a DEAC szellemiség}

A Debreceni Egyetemi Athletikai Clubot 1919. augusztus elsején alapították egyetemi vezetők, professzorok, neves közéleti személyiségek azzal az elsődleges céllal, hogy az egyetemi hallgatóknak, oktatóknak és dolgozóknak sportolási lehetőséget biztosítsanak. Sándor Mihály kiváló debreceni sporttörténész adatai szerint a sportegyesület futball- és atlétikai szakosztálya 1919. augusztus 13-án, szerdán, délután 5 órakor alakult meg.

A labdarúgó szakosztály mintegy 20 éves története kb. 1954-től 1974-ig több korszakra osztható. Bár már korábban is sok jól felkészült, tehetséges játékos és sportvezető tevékenykedett az egyesületnél, a csapat igazi hírnevét, elismertségét az 1940-es évek legvégének és az 50-es évek elejének játékosai, vezetői teremtették meg. Ebben az időben alakult ki és érte el világraszóló eredményeit Puskásék Aranycsapata is.

A DEAC együttese egyre jobb eredményeket elérve 1957-ben bejutott az akkor nagyon színvonalasnak számító Nemzeti Bajnokság harmadik osztályába. Az alapokat lerakó első nagy játékosnemzedékbe tartozott többek között Oltványi Ottó, Barkai László, Gál János, Halász Attila, Hernádi Ferenc, Bíró Imre, Zsoltvai Attila, Balogh 
János, Fóris István, Sándor József, Jakab Albert, Kalina István, Halmai Zoltán, Fehérvári Andor, Kundrák István, Nyirkos István, Katona Sándor, Vaskó László, Varga Iván, Soltész István. Ide sorolható még Szegedi Gyula, Szűcs János, Kassai László és Kéki Miklós is. Ők életkoruknak és hosszú sportpályafutásuknak köszönhetően még a 60-as évek nagy csapatában is alapvető szerepet játszottak.

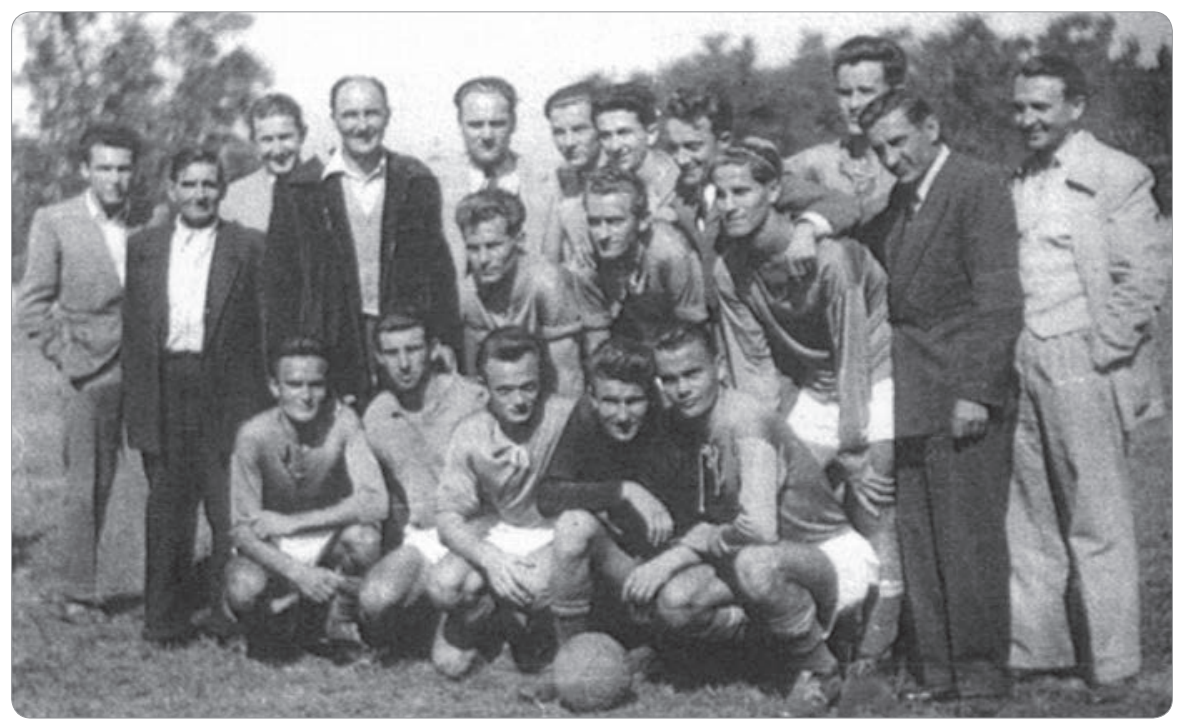

1. kép. A területi bajnokság gyöztes csapata (1954)

Ebben a népszerűséget megalapozó korszakban az edzői teendőket dr. Fehér Rudolf, Sidlik István, Kántor Dezső, Palotás István, dr. Thomas Henrik és Szarvas Albert látta el. Szakosztályvezetőként, intézőként, egyéb sportvezetőként segítette a csapat munkáját többek között: Aross Béla, dr. Varga Miklós, dr. Karmazsin László, dr. Csicsai József, Balázs Sándor.

A második sikeres időszak az 1960-as évek elejére esik, amikor a csapat az NB III-as bajnokságot nagy fölénnyel megnyerve két évig a második vonalnak számító kétcsoportos NB II, Keleti csoportjában szerepelt.

Ezt követően váltakozó, hullámzó NB III-as helyezések után, 1969-ben újra bajnokságot nyerve az 1970-es évekre ismét kiváló együttes jött létre, amely az NB I B miatt (1963-1974) a harmadik osztálynak tekintett háromcsoportos NB II-ben négy és fél éven keresztül ért el nagyszerű eredményeket.

A DEAC labdarúgók szinte minden korszakban - kevés kivételtől eltekintve - mind egyetemi hallgatók, diákok voltak. A kezdetektől a DEAC szellemiséghez tartozott az egyetemi és a sportvezetők tisztelete, a jó modor, a barátság, az összetartozás, egymás tanulmányi és sporteredményeinek megbecsülése, a közösséghez tartozás fontossága, az ellenfelek tisztelete, az önkritikus önszemlélet, a bölcs belátás és kiemelten a tanulás elsődlegessége. 
A játékosokat a politika, a közélet eseményei kevésbé foglalkoztatták. Figyelmük, idejük nagy részét zömmel a versenysport, az edzések, a tanulás, a vizsgák, fiatal életkorukból következően az udvarlás, a magánélet kötötte le. Ennek ellenére a politika, a közélet kérdéseiben sem voltak teljesen tájékozatlanok. Beszédtéma volt köztük például a hidegháború időszakának legforróbb pillanata, az 1962-es kubai rakétaválság és más, hasonló kül- és belpolitikai esemény.

A labdarúgók közül elég sokan figyelemmel kísérték, időnként látogatták is a város művészeti, kulturális rendezvényeit, eseményeit. Módjukban volt megtekinteni - és éltek is a lehetőséggel - a Munkácsy Mihály-díjas (1956), Kossuth-díjas (1961) grafikus, festő Holló László műveit, festményeit. Ezeket az alkotásokat ez idő tájt gyakran mutatták be a Déri Múzeumban rendezett kiállításokon. Néhányan még az 1955-től nemzetközi hírnévnek örvendő Kodály Kórus fellépéseire is elmerészkedtek. Szívesen nézték és hallgatták a könnyüzene jelentősebb eseményeit, az 1966-tól rendezett táncdalfesztiválokat, Koós János, Kovács Kati, Koncz Zsuzsa, Zalatnai Sarolta énekesi pályájának kibontakozását, az Illés, a Metró, az Omega zenekarok fellépéseit. Többen rendszeresen látogatták a Csokonai Színház bemutatóit, előadásait. Nem tudhatták, de még a színházi szakemberek közül is csak nagyon kevesen sejthették, hogy az akkor általuk színpadon látott két színész, Latinovics Zoltán és Hofi Géza, rövidesen milyen szédületes művészi karriert fog befutni.

A játékosok legnagyobb része később a civil életben is helytállt, sőt sokan közülük szakmájuk legkiválóbbjai lettek. Akad(t) köztük akadémikus, orvosprofesszor, nyelvész egyetemi tanár, kórházigazgató, országos hírü radiológus, kardiológus, számtalan neves egyéb szakorvos, művelődésügyi osztályvezető, neves újságíró, magas beosztású bíró. Többen doktori címet, sokan másoddiplomát szereztek, jó néhányan tudományos fokozatokat értek el. Mások megbecsült, kiváló középiskolai tanárok, vegyészek lettek.

Tévedés ne essék, de ezek a labdarúgók sem voltak angyalok. Előfordult több sportfegyelmi, magánéleti kilengés, néha tanulási és magánéleti kudarc is, összességében és hosszú távon azonban a szereplők betartották a fair play, a DEAC szellemiség, hivatásuk, szakmájuk írott és íratlan szabályait.

\section{Néhány meghatározó játékos arcképvázlata az elsö korszakból}

Az 1950-es évek egyetemi csapatának meghatározó játékosa, majd közel 40 évig a DEAC emblematikus sportvezetője volt dr. Nyirkos István (1933-2013), akinek több évtizedes tudományos, oktatói és tudományszervezői munkássága is példaértékű.

Középhátvédként játékát a nagyszerü helyezkedés, remek irányítókészség, jó fejjáték, intelligencia jellemezte. A korabeli sporttudósítások szinte valamennyi mérkőzésén a jók között vagy a mezőny legjobbjaként emlegették. Többször szerepelt az NB III-as megyeválogatottban. Több első osztályú csapat is szerette volna leigazolni, de ő hủ maradt a DEAC-hoz, az egyetemhez. 


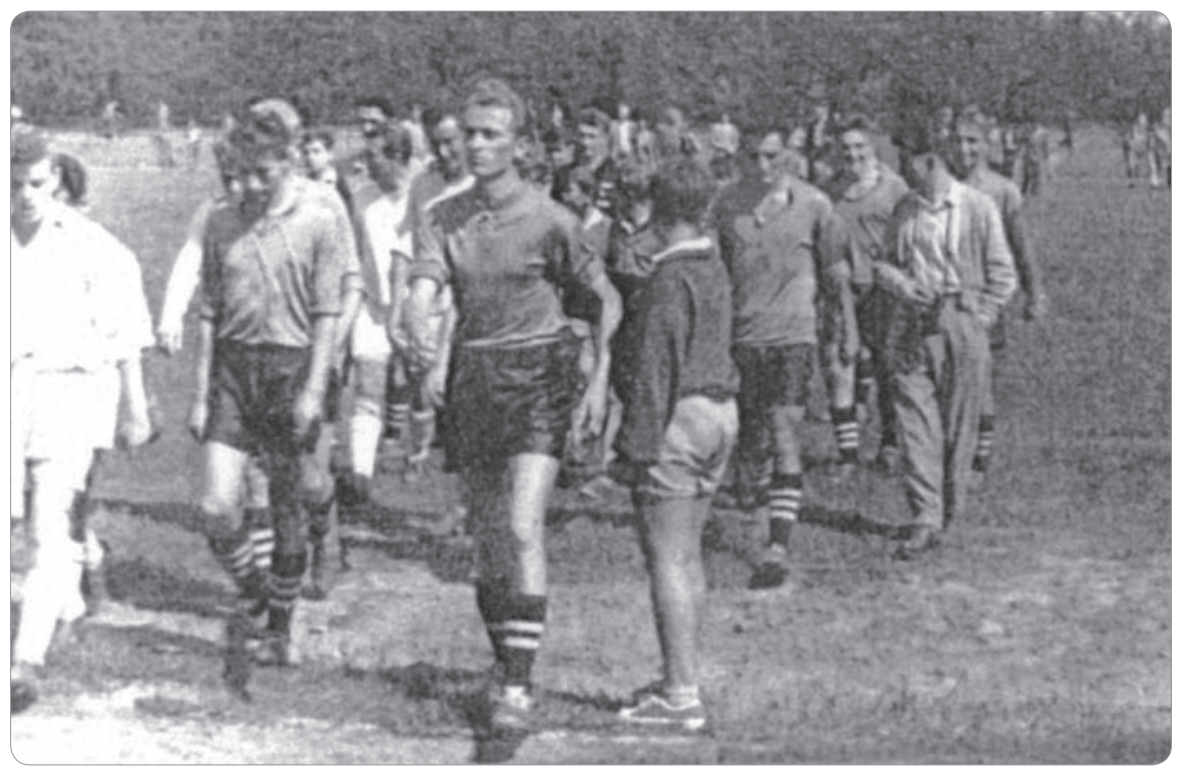

2. kép. Nyirkos István 1956-ban

Hosszú és rendkívül eredményes sportvezetői, klubelnöki tevékenységét az egyesület és az egyetem 2001-ben tiszteletbeli és örökös sportelnöki címmel ismerte el.

Magyar nyelv és irodalom szakos diplomájának megszerzése után rendkívüli tehetsége és szorgalma révén egyetemi oktatói és tudományos karrierje is gyorsan kibontakozott. Bölcsészdoktori, majd akadémiai doktori címet szerzett. 1995-től egyetemi tanár, majd a Finnugor Nyelvtudományi Tanszék vezetője. Előtte 1963 és 1976 között a Helsinki Egyetem magyar lektora, később, 1987-től a finn fővárosban működő Magyar Kulturális és Tudományos Központ igazgatója. Szótárt szerkesztett, tankönyveket írt, fordított, delegációkat vezetett, testvérvárosi kapcsolatokat segített életre nemcsak Finnországban, de időnként Észtországban is. Neves politikusok, közéleti személyiségek - például Kekkonen finn köztársasági elnök - vették igénybe tolmácsként szolgálatait. 1984 és 1987 között a KLTE BTK dékánhelyettese, 1995-től 1998-ig oktatási és általános rektorhelyettes. 20 könyve és csaknem 200 tanulmánya jelent meg. 2003-ban kapta meg a professor emeritus címet. Számtalan kitüntetése közül a Finn Fehér Rózsa Lovagrend I. fokozata, a Finn Akadémia Emlékérme, a Magyar Köztársasági Érdemrend Kiskeresztje a legfontosabb.

Dr. Nyirkos Istvánnak a Juha Richárd szobrászművész által készített bronz mellszobrát 2016. október 5-én dr. Bács Zoltán egyetemi tanár, kancellár és dr. Bitskey István professor emeritus, a DEAC akkori elnöke avatta fel az egyetemi sporttelep délkeleti sarkán, nem messze Buzánszky Jenő egész alakos szobrától.

Dr. Nyirkos István legjobb barátja és egyben játékostársa a még ma is aktív dr. Katona Sándor volt, aki képzett, kemény, de sportszerű hátvédként 1948 és 1956 között csapatkapitányként, a pályán és a pályán kívül is az együttes szellemi vezéreként 
tevékenykedett. Gyors volt, jól fejelt, nagyon jó rúgótechnikával rendelkezett. Rendszeresen játszott a megyeválogatottban, később Debrecen öregfiúk válogatottjában is.

Fehérgyarmat föorvosaként, a kórház igazgatójaként, nagyon elismert közösségi és sportmunkájáért, a település sokirányú fejlesztéséért kapta meg több magas rangú kitüntetését, valamint a város díszpolgára címet.

Hobbija a vadászat. Többszörös Nimród-díjas mestervadász. A DEAC labdarúgó relikviáinak szorgalmas gyűjtője. A régi játékosok, sportvezetők, hozzátartozók találkozóinak önzetlen, nagyvonalú támogatója. Tisztelet, szeretet, megbecsülés övezi város- és megyeszerte már-már legendás alakját.

A nagy öregek csapatában fedezetként, középpályásként nagyon hasznos, kiegyensúlyozott játékra volt képes dr. Vaskó László (1931-2014). Kitüntetéssel megszerzett történelem szakos diplomájának átvétele után „summa cum laude” lett bölcsészdoktor, később adjunktus, majd docens. 1989-től a Neveléstudományi Intézetet vezette 1995-ös nyugdíjba vonulásáig.

A Mezőkövesdről induló és később oda visszatérő elválaszthatatlan két jó barát, dr. Varga Iván és dr. Soltész István, 1953-tól 1959-ig erősítette az egyetemi labdarúgó kollektívát.

Dr. Varga Iván nagyon magas színvonalon látta el a védekező középpályás feladatait. Ragyogó fejjátéka, játékintelligenciája, játékostársainak a gondolatát is előre ismerő képessége, jó ütemű indításai aranyat értek a csapatnak.

Dr. Soltész István kezdetben csatárként szerepelt, később a tapasztalt és jószemü edző, Szarvas Albert hatására stabil, megbízható balhátvéd lett. Rendkívül lelkes, kemény játékstílus volt a sajátja. Jó ideig a csapatkapitányi karszalagot is ő viselte. Orvosként két szakvizsgát tett: sebész és urológus szakorvos lett. Debrecenben elöször sebészként dolgozott, majd mint urológus szerzett magas fokú szakmai elismertséget és klinikai főorvosi rangot. Nyugdíjasként félig visszaköltözött Mezőkövesdre, és a mai napig ott is kamatoztatja kivételesen széles körü orvosi tapasztalatát.

Dr. Varga Iván orvosként rövid ideig Egerben dolgozott, majd 45 éven keresztül, máig Mezőkövesd nagyon felkészült, szeretett, tisztelt háziorvosa. Munkásságát többek között dr. Szűcs Géza-díjjal jutalmazták.

Nemzetközi hírü, aranykoszorús boxerkutya tenyésztő. Nemzetközileg elismert boxer és angol bulldog versenybíró.

\section{A megerösödés évei}

1957 fontos évszám az egyesület történetében. A Kossuth Lajos Tudományegyetem és az Orvostudományi Egyetem képviselői - dr. Szabó István gazdaságtörténész profeszszor tanárelnökkel az élen - új vezetőséget választottak és újjászervezték a sportegyesületet. A D. Haladás SK helyett visszavették a klub hagyományos nevét. Megerősítették azt az elvet, hogy a DEAC tagjait elsősorban az egyetemi hallgatók, oktatók és dolgo- 
zók köréből kell toborozni. Biztosították 12 szakosztály működési, fejlődési feltételeit. A sakkozók az OB I-re, a kézilabdázók, a kosarasok és a röplabdások az OB II-re, az NB III-ba bejutott labdarúgók sikeres szereplésre készültek.

A labdarúgó szakosztályvezetés intenzív és kiterjedt csapatépítésbe kezdett. Pótolni kellett az idősebb visszavonuló játékosokat, tovább kellett erősíteni a csapatot. Egyetemi oktatók, hallgatók, DEAC szimpatizánsok bevonásával még a távolabbi megyékben is keresték, kutatták a leigazolható, tehetséges játékosokat. Ebben a kutató, előkészítő munkában a csapat intézője, a mindenki által tisztelt és szeretett Balázs Sándor és a későbbi sikeres edző, Bódor Lajos járt az élen. Időnként a Debrecenbe jelentkező sportolóknak intenzív egyetemi felvételi előkészítő tanfolyamokat szerveztek. Ekkor olyan játékosok kerültek a csapathoz, akik a későbbi sikerekben jelentős szerepet játszottak.

Az őszi-tavaszi rendszerủ bajnokságban az együttes évente egyre jobb helyezést ért el. 1957/58-ban a hatodik, 1958/59-ben a harmadik, 1959/60-ban a nagyon erös Nyíregyházi Spartacus mögött a második helyen zárta a szezont. Ekkor a szakmai irányítást két kiváló edző, kezdetben dr. Thomas Henrik ügyvéd, majd Szarvas Albert egyetemi gondnok látta el. Ezekben az években a bajnokság mellett megyék közötti felnőtt és iffúsági NB III-as válogatott-találkozókat is szerveztek. Hajdú-Bihar megye válogatottjának 70-80\%-át az egyetemisták adták.

\section{A legsikeresebb idöszak}

1960 nyarán új edző került a csapathoz. Szilárd Elek, a népszerü és nagy tekintélyü szakvezető játékos korában az első osztályú Temesvári Kinizsiben, a Kolozsvári ACben és a DVSC-ben játszott jobbszélsőt. Egyszer a román válogatott mezét is magára ölthette.

Az új edző egyaránt szakszerủen és jó érzékkel végezte az együttes technikai, taktikai, erőnléti és lélektani felkészítését. Ehhez komoly segítséget kapott az együttműködő és hozzáértő szakmai stábtól: dr. Szilágyi Tibor szakosztályi elnöktől, dr. Csorba Sándor szakosztályvezetőtől és Balázs Sándor intézőtől. Mindezek és a megnövekedett önbizalmú labdarúgók tehetsége, tudása, lelkesedése, összetartása következtében a csapat legsikeresebb hároméves időszaka következett. Sorra jöttek az eredmények.

1960 őszén a DEAC először nyert országos főiskolai labdarúgó-bajnokságot az NB I-es játékosokat is felsorakoztató Szegedi EAC előtt. Egy év múlva fordított sorrend született. Röplabdában viszont ekkor veretlenül a debreceni férficsapat lett az első. A labdarúgó együttes az 1960/61-es idényben 7 pont előnnyel - 30 mérkőzésből mindössze 2 vereséggel - szerezte meg a bajnoki címet a Debreceni Gördülőcsapágygyár gárdája előtt az NB III Észak-keleti csoportjában. Ezzel bekerült a második osztályba, az NB II-be, ahol két évig szerepelt. A 21,5 éves átlagéletkorú bajnokcsapat folyamatosan, 23 fordulón keresztül, az országban egyedül volt veretlen a Nemzeti Bajnokság 3 osztályának 142 csapata közül. 


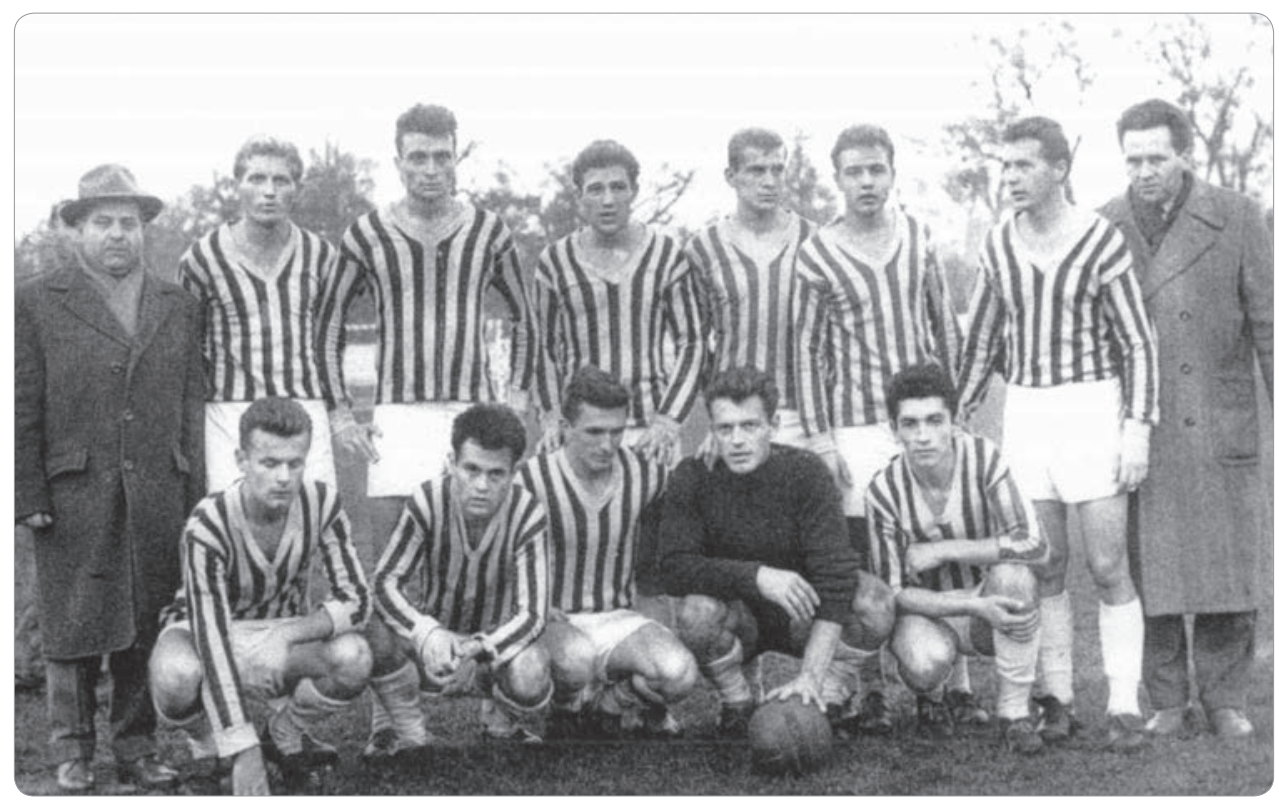

3. kép. Az NB II-es DEAC 1961 öszén

A bajnokcsapat játékosai: Kassai (29), Márai (1), Környei (30), Móricz (29), Varsányi (30), Szabó József (1), Temesvári Miklós (30), Cséfalvai (30), Stefanik (24), Szűcs János (26), Szegedi dr. (24), Kéki (29), Filetóth (29), Gápel (9), Mályi (7), U. Szabó (1).

A gólszerzők: Szűcs János 15, Stefanik 12, Filetóth 10, Kéki 10, Szegedi dr. 7 , Gápel 7, Varsányi 5 (4-et tizenegyesből), Mályi 1, Cséfalvai 1.

A csapat tanulmányi átlaga 4,12 volt, jobb, mint az egyetemi átlag. Az együttes futballsikereit méltató újságcikkek a kiemelkedő tanulmányi eredményeket is dicsérték (Hajdú-bihari Napló, 1961. június 11., Fülep Kornél; Népsport, 1961. július 16.).

1961 júliusában az újonc NB II-es gárda játékosa lett Dévai László (Miskolci MTE), Várhelyi Gusztáv (Borsodi Bányász), Bartha József (Törökszentmiklósi Fáklya), Ladányi Zoltán (Sátoraljaújhely). Velük tovább erősödött, bővült a játékosállomány.

Az NB II-es szereplés első évében, az 1961/62-es szezonban a csapat nagyszerűen helytállt. Például 1961 szeptemberében az újonc DEAC a Nagyerdei Stadionban 12 ezer néző előtt a helyi rangadón Szűcs János góljával 1:0-ra legyőzte a későbbi bajnok Debreceni VSC-t. Nem járt jobban a másik volt első osztályú csapat sem. A neves Bukovi Márton edzette Diósgyőri VTK a kibővített egyetemi pályán 7 ezer érdeklődő előtt szenvedett 2:0-as vereséget Filetóth László és dr. Szegedi Gyula góljaival 1962. április 3-án. Tizenöt nap múlva Bozsik József Uruguay ellen döntetlent érő góllal ünnepelte akkor 100-diknak tartott, azóta 101-diknek elismert válogatottságát. Májusban, júniusban az 1962-es chilei labdarúgó világbajnokságon Grosics, Mészöly, Sándor, 
Albert, Tichy és mások vezérletével, Baróti Lajos szövetségi kapitány irányításával a magyar válogatott az ötödik helyen végzett.

1962 májusában avatták „Sub auspiciis Rei Publicae popularis” kitüntetéssel orvosdoktorrá Szegedi Gyulát. A magyar labdarúgás történetében addig, de talán azóta is példátlan tanulmányi és sportolói teljesítménye alkalmából az MLSZ akkori elnöke, Barcs Sándor nyílt levélben „a magyar labdarúgás büszkeségének [...] az egész sportoló magyar iffúság példaképének" nevezte a játékost.

Az 1961/62-es bajnokság befejezésekor az egyetemi csapat az NB II Keleti csoportjában a 16 együttes közül a nyolcadik helyet szerezte meg. Ezzel a másodosztályba bejutott 6 újonccsapat közül a legjobban szerepelt. Az otthoni átlagnézőszám meghaladta a 4 ezret. A bajnokságot a DVSC nyerte.

A nyolcadik helyet megszerző DEAC játékosok: Kassai dr. (27), Márai (1), Bartha (1), Ladányi (1), Környei (30), Móricz (30), Varsányi (15), Várhelyi (15), Temesvári Miklós (30), Cséfalvai (29), Kéki (26), Stefanik (14), Szűcs J. (27), Dévai (22), Szegedi dr. (22), Filetóth (22), Gápel (11), Mályi (7), U. Szabó (1), Temesvári Tibor (1).

Gólszerzők: Filetóth 6, Stefanik 5, Szűcs J. 4, Temesvári Miklós 4, Kéki 4, Környei 2, Szegedi dr. 2, Gápel 2, Dévai 1, Móricz 1.

1962 nyarán igazolta le az akkor már egy éve NB II-es csapat Buglyó Tibor középpályást és csatárt (D. Kinizsi), Veress Gábor csatárt (Láng SK), Perjési Levente csatárt (Kazincbarcikai Vegyész), László Csaba kapust (Kisvárdai Vasas), Kenyeres Sándor védőt (Hajdúnánási Spartacus). Eltávozott viszont Kassai László kapus kivételével a teljes közvetlen védelem: Környei L. (Dorog), Móricz S. (Bp. Honvéd), Varsányi A. (DVSC). Ez a későbbiekben sok gondot okozott.

Az NB II-es szereplés második évében a csapat hullámzó teljesítményt nyújtott. Összeállítási, taktikai gondok jelentkeztek. Önbizalomhiány, dekoncentráltság, sérülés, betegség, edzéshiány, formaingadozás lépett fel. A csapategység meggyengült. Az együttes a bajnokság félidejében a tabella 13., még nem kieső helyén várta a tavaszi folytatást. A problémák megoldását, a fenyegető kiesés elkerülésének módját a vezetőség egy része és néhány játékos az edzőcserében látta. 1963 januárjában a kispadon Szilárd Eleket a D. Kinizsi volt játékosa, Csende Sándor testnevelö tanár váltotta fel.

A tavaszi rajt kezdetben jól sikerült, két győzelemmel és két döntetlennel, de később egymás után hat vereség következett, ebből három hazai pályán. A hátralévő öt találkozó sem hozott fordulatot. Az új edző, a régi szakosztályvezetés, a régi és az új játékosok minden erőfeszítése ellenére sem sikerült a játék színvonalát,az eredményességet kellöen megemelni, a csapatban, a labdarúgókban kétségkívül meglévő kvalitásokat felszínre hozni. Végül az egyetemi csapat két év után, utolsó helyezettként, kiesett a másodosztályból. Ezt a tényt a szereplők máig nem tudták sportszakmailag teljesen feldolgozni, lélektanilag megnyugtatóan elfogadni.

Az 1962/63-as idény játékosai: Kassai dr. (30), Temesvári Tibor (30), Szegedi dr. (12), Várhelyi (30), Temesvári Miklós (20), Cséfalvai (23), Buglyó (26), Szűcs J. (25), Veress Gábor (29), Kéki (27), Filetóth (26), Stefanik (14), Dévai (28), Gápel (4), Perjési (3), Szikszai (2). 
Gólszerzők: Veress Gábor 8, Buglyó 6, Filetóth 4, Kéki 3, Stefanik 3, Várhelyi 2, Cséfalvai 1, Dévai 1 .

\section{Az átmeneti idöszak}

A szakosztály történetének 1963-tól 1969-ig tartó átmeneti korszaka következett. Ez a periódus váltakozó szerepléssel a másodosztályból való kieséstől az NB III-as bajnokság újbóli megnyeréséig tartott.

1963-ban jelentős változások történtek a csapat játékosállományában. Az előző időszak több meghatározó szereplője távozott. A régi gárdához sorolható labdarúgók közül hozzávetőleg heten a csapatnál maradtak. Erősítésként leigazolták a kiváló adottságokkal rendelkező borsodi ifiválogatott középhátvédet, Heinrich Gábort, aki rövidesen magyar ifiválogatott lett, valamint a tehetséges balszélsőt, Polák Zoltánt, a Váci Petőfiből.

1963 nyarán szerkezetében és lebonyolítási rendszerében is átszervezték a labdarúgó Nemzeti Bajnokságot. Megalakult az NB I/B és fennmaradt 1974-ig. Az NB II eddigi két csoportja helyett hármat hoztak létre, az NB III hatcsoportos lett. A kiesett DEAC az NB III Észak-keleti csoportjába került. Az őszi-tavaszi lebonyolítási rendszert tavaszi-őszi váltotta fel. Minden osztályban őszi félfordulós bajnokságot rendeztek. A még mindig jelentős játékerőt képviselő egyetemi gárda Csende Sándor irányításával csoportjában a második helyen végzett.

1964-ben nyolcadik, 1965-ben tizedik az együttes, és sikerült újra országos főiskolai bajnoki címet nyerni. A szakvezető ekkor már ismét Szilárd Elek volt. 1966-tól 1971/72-ig, betegségéig, dr. Bódor Lajos a labdarúgók mestere. 1966-ban tizenötödik, 1967-ben a D. Elektromos mögött a második, 1968-ban a negyedik a gárda. Ekkor a sportszerűségi versenyt is megnyerték. Ebben az évben jelentősen változott a játékosállomány. Heinrich Gábor és Veress Gábor az NB II-es DVSC-be távozott. László Csaba kapus az FTC-be ment, ahol nemsokára kétszer is aranyérmet nyert a tartalékcsapattal. Leigazolták az NB I-es Tatabányából az ifiválogatott csatárt, Bencze Sándort, az Egri Dózsából a többszörös UEFA válogatott védőt, a nagyon fiatal Csapó Kálmánt és az Egri Dózsával az első osztályt is megjárt támadót, Tóth Józsefet.

Említésre méltó eseménye még az 1968-as évnek, hogy a Debreceni Agrártudományi Sportegyesület (a DASE) megnyerte a megyei bajnokságot, és bekerült az NB III-ba. Az együttes kapusa az a Csank János volt, aki edzőként 1994-ben a Váccal, 2001-ben az FTC-vel nyert bajnokságot, 1996 és 1998 között 19 mérkőzésen volt szövetségi kapitány. Megkapta a mesteredzői címet is.

1969-ben ünnepelte a sportegyesület megalakulásának 50. évfordulóját. Ebből az alkalomból ünnepi közgyủlést tartottak a KLTE Aulájában, amelyen részt vettek egykori és akkori sportolók mellett a párt- és tömegszervezetek küldöttei, valamint a lengyel testvérváros, Lublin sportolóinak képviselői is. Tartalmas jubileumi műsorfüzetet adtak ki és Magyar öregfiúk válogatott - DEAC öregfiúk mérkőzést rendeztek 3 ezer 
néző előtt, amelynek 5:1 lett a végeredménye. Gólszerzők: Szusza 3, Szojka, Budai, illetve Várhelyi.

1969 és 1971 között dr. Albert Béla professzor, a Szemészeti Klinika igazgatója volt a DEAC elnöke. Ekkor a sportegyesület 12 szakosztályában mintegy 500-an sportoltak.

\section{6. Újabb bajnokcsapat. Ismét az NB II-ben}

1969-ben egy országosan rendkívül szomorú, helyileg viszont egy nagyon örvendetes sportesemény történt. 1969 decemberében a Magyar labdarúgó-válogatott, történetében először, sajnos nem jutott ki az 1970-es mexikói világbajnokságra, mert Marseilleben, az erről döntő mérkőzésen ,jöttek a csehszlovákok” (4:1).

Debrecenben viszont örülhettek a DEAC szurkolói és szimpatizánsai, mert 1969-ben egy új, 5 és fél évig tartó sikeres időszak kezdődött a szakosztály történetében.

Hét év után 4 pont előnnyel újra bajnokságot nyert a csapat az NB III Észak-keleti csoportjában, és bekerült az NB II-be. Kiesett a DASE és a D. Kinizsi. Visszakerült az NB I. B-be a Debreceni DVSC. A bajnokcsapat edzője, dr. Bódor Lajos, szakosztályvezetője az együttes régi, legendás játékosa, dr. Szűcs János, szaktanácsadója Palotás István volt. Szakosztályvezetőségi tagként id. Puskás László a szövetségi képviselői tisztséget töltötte be.

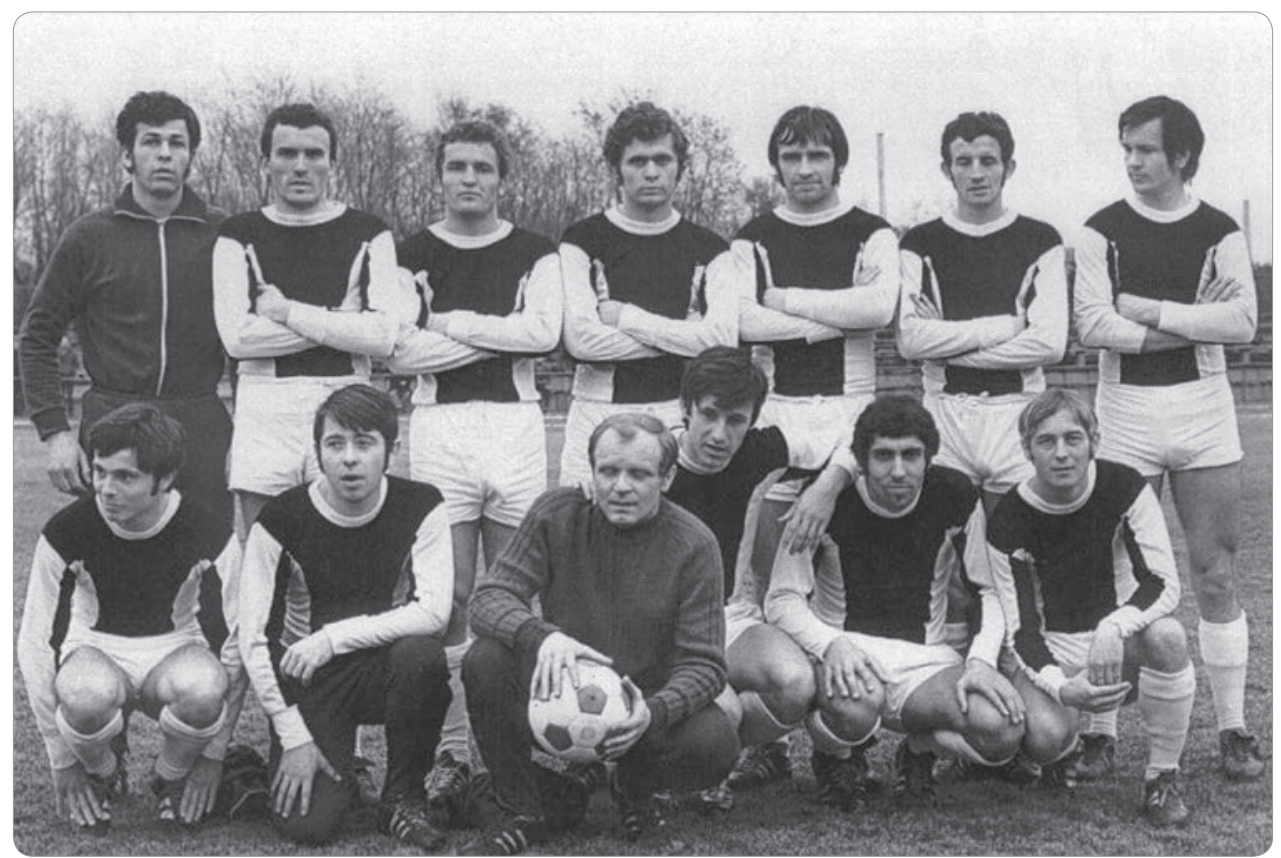

4. kép. Az NB II-es együttes 1972-ben 
A játékosok: Pálchuber Károly (30), Varga (5), Puskás L. (28), Tamás (6), Csapó (28), Bene (21), Fülep (6), Bíró II. (29), Szulyovszki (15), Maróti (16), Kéki dr. (14), Tóth J. (28), Bencze (30), Bíró I. (8), Hegedűs (22), Kiss László (29), Szabó Gábor (28), Loós (6).

A 65 gól szerzői: Szabó G. (24), Kiss L. (12), Bene (7), Maróti (7), Tóth J. (5), Hegedűs (4), Bíró II. (3), Bíró I. (2), Loós (1).

1970-ben visszatértek az őszi-tavaszi lebonyolítási rendszerre, ezért ebben az évben csak tavaszi félidényes bajnokságot rendeztek, ekkor se feljutó, se kieső csapat nem volt. Az újonc NB II-es DEAC 1970-ben a kilencedik helyen végzett. Jól szolgálta a következő szezonra való felkészülést a júliusi lengyelországi túra, ahol három mérkőzésen, nagy közönség elött kilenc gólt rúgott az együttes (Kiss L. 5, Szabó G. 3, Tóth J. 1).

1970/71-ben, az első teljes idényben a hatodik helyet szerezte meg a gárda, megelőzve a másik két debreceni csapatot, az MGM Vasast és a D. Honvéd Bocskait. „Akinek tanulmányi problémái vannak, az nem futballozhat. Elsö a tanulás!" - nyilatkozta a Hajdú-bihari Naplónak dr. Bódor Lajos szakvezető 1971 júliusában. A helyezéssel elégedett volt, a hátsó alakzat játékával kevésbé. Ebből a csapatrészből Csapó Kálmán és Szulyovszki egyenletes, sallangmentes teljesítményét emelte ki. Elismeréssel szólt Bencze és Tóth József taktikai felkészültségéről. A támadók közül még a gólveszélyes Kiss Lászlót és a nagyon jól cselező Szabó Gábort dicsérte. Leigazolták a nagyon tehetséges csatárt, Gottdiener Sándort, akit több egyesület is szeretett volna megszerezni. A szakosztályvezetés sokallotta a szezon alatti négy kiállítást.

Az 1971/72-es bajnokságban sikerült megismételni az előző évi hatodik helyezést. Az idény végén immár hagyományosan a helyi lapnak, Filep Kornélnak nyilatkozott az egész szakosztályvezetés nevében dr. Bódor Lajos. Elmondta, hogy az év folyamán valamennyi játékos teljesítményét osztályozták. A legjobban szerepeltek: Csapó 4,5; Szulyovszki 4,4; Puskás 4,2; Tóth J. 4 ,1; Pálchuber és Gottdiener 3,9. A 47-ből Kiss L. 11, Gottdiener 10, Tóth J. és Szabó G. 9-9 gólt szerzett. Kiállítás nem fordult elő, viszont 4 játékos ellen indult fegyelmi eljárás. Egy kivételes teljesítmény is füződik a csapat nevéhez. Az egész Nemzeti Bajnokságban a legnagyobb arányú győzelmet a DEAC együttese aratta 1972. július 20-án a Szarvasi Főiskola, Spartacus 10:1-es legyőzésével. Ez év nyarán rendezték meg Romániában a harmadik főiskolai labdarúgó Európa-bajnokságot, amelyen a DEAC két orvosegyetemista játékosa, Csapó Kálmán és Szabó Gábor is szerepelt. A magyar csapatban játszott még mások mellett Bicskei Bertalan (Bp. Honvéd, TF) is, a későbbi mesteredző, aki negyvenöt mérkőzésen töltötte be a szövetségi kapitányi tisztséget. A magyar föiskolai együttes nagy közönség előtt sikert aratott a belgák és a franciák ellen, de a spanyolok megakadályozták (0:1) a legjobb 4 közé jutást.

Az 1972/73-as idény rosszul kezdődött. 1972 őszén dr. Bódor Lajos hét év után, betegsége miatt kénytelen volt átadni az edzői tisztet Juhász Gyulának, a DVSC volt labdarúgójának. Dr. Bódor Lajos felgyógyulása után szakosztályvezetőként segítette a csapat munkáját. A bajnokság végén az együttes változatos szereplés után a táblázat kilencedik helyén kötött ki. Gottdiener 12 góllal lett a gólkirály. 
Varga kapus bebizonyította, hogy lehet rá számítani. Több fiatal játékos, Szabolcsi, Luterán, Filetóth János bejátszotta magát az együttesbe. A bajnokság végén Juhász Gyulát, a volt nagyszerü kapus, Nagy Mihály váltotta fel, aki gyorsan megtalálta a DEAC-hoz legjobban illő taktikát, mert a gárda a nyári totókupában csoportjában veretlenül az élen végzett.

Ritka dolog történt az 1973/74-es szezon egyik mérkőzésén. 1973. október 9-én Debrecenben az egyetemi csapat 5:2-re győzte le a Kecskeméti TE alakulatát. Mind az öt gólt egy játékos, Kiss László szerezte („mesterötös”).

1974. június 16-án fejeződött be a bajnokság. Az utolsó fordulóban az ezer néző előtt lejátszott helyi rangadót a DEAC magabiztosan, 3:1-re nyerte meg a DMTE ellen. Ezzel a csapat az ötödik helyen zárta a bajnoki évadot és egyben NB II-es szereplését.

A négy és fél év alatt a DEAC-ban játszó labdarúgók (kb. időrendben):

Pálchuber, Varga Gy., Fóhn, Csapó, Szulyovszki, Molnár, Bene, Bencze, Hegedűs, Kiss L., Kiss S., Szabó G., Tóth J., Bíró Pál, Petróczki I., Bíró Szabolcs, Puskás L., Csathó, Tulák, Somogyi, Zilahi, Petróczki II., Gottdiener, Szabolcsi, Filetóth János, Luterán, Matus, Magyar, Turcsek, Bereczki, Terdik, Simon, Bujdosó A., Bujdosó J., Erdős...

1974-ben szerkezetében újra átalakították a bajnoki rendszert. Tíz év után megszűnt az NB I. B és vele együtt az eddigi 3 NB II-es csoport. Helyettük egycsoportos NB II jött létre 20 csapattal. Ebbe a DEAC helyezése alapján nem került be (A DVSC igen).

Négy NB III-as csoport alakult. Az egyetemi együttes az Észak-keleti csoportba nyert besorolást.

Az 1974/75-ös idényben a csapat nagyon gyengén teljesített és kiesett az NB IIIból, a megyei első osztályba és nagyon hosszú ideig, 2017-ig ott játszott. Ez alól kivételt jelentett a Debreceni Univerzitás Sportegyesület, a DUSE 1979-89-es időszaka. Ekkor a DUSE labdarúgói 3 évig a háromcsoportos, egy évig a kétcsoportos, 6 évig a harmadik vonalnak számító területi bajnokság Tisza-csoportjában szerepeltek. Az új sportklub egyesítette Debrecen valamennyi felsőfokú oktatási intézményének sportegyesületét: a DEAC-ot, a DASE-t, az Ybl Miklós Műszaki Főiskola és a Tanítóképző Főiskola Sportegyesületét.

Az új sportkört a városi tanács, üzemek, intézmények is támogatták. Az egyetemi, föiskolai sportolók bizonyos mértékig háttérbe szorultak. Például 1983 augusztusában a labdarúgócsapatból mindössze négyen jártak felsőfokú intézménybe.

Az 1991-től újra önálló, független DEAC labdarúgó együttese 2017-ben megnyerve a megyei bajnokságot és az osztályozót, ismét bekerült a Nemzeti Bajnokság harmadik osztályába. Gratulálunk a nagyszerű eredményhez. Jelenleg a szakosztály 3 felnőtt és 14 korosztályos csapatot működtet.

Bár a sportot és benne a labdarúgást is alapvetően meghatározó, alakító politikai, gazdasági, társadalmi körülmények gyökeresen megváltoztak, a lehetőségek adottak, ezért reménykedve várjuk az 1960-as, 70 -es évekhez hasonló, sikeres időszak újbóli eljövetelét. 


\section{DEAC játékosok NB I-es csapatokban}

Ebben a közel 20 éves időszakban összesen 10 egyetemi futballista játszott első osztályú csapatban. Hatan az 1960-as, négyen az 1970-es évek együtteseiből. Az előbbiek közül mind a hatan a DEAC-ból kerültek NB I-es csapatba, az utóbbiak közül négyből ketten. A másik kettő első osztályú együttesből igazolt a DEAC labdarúgó közösségébe.

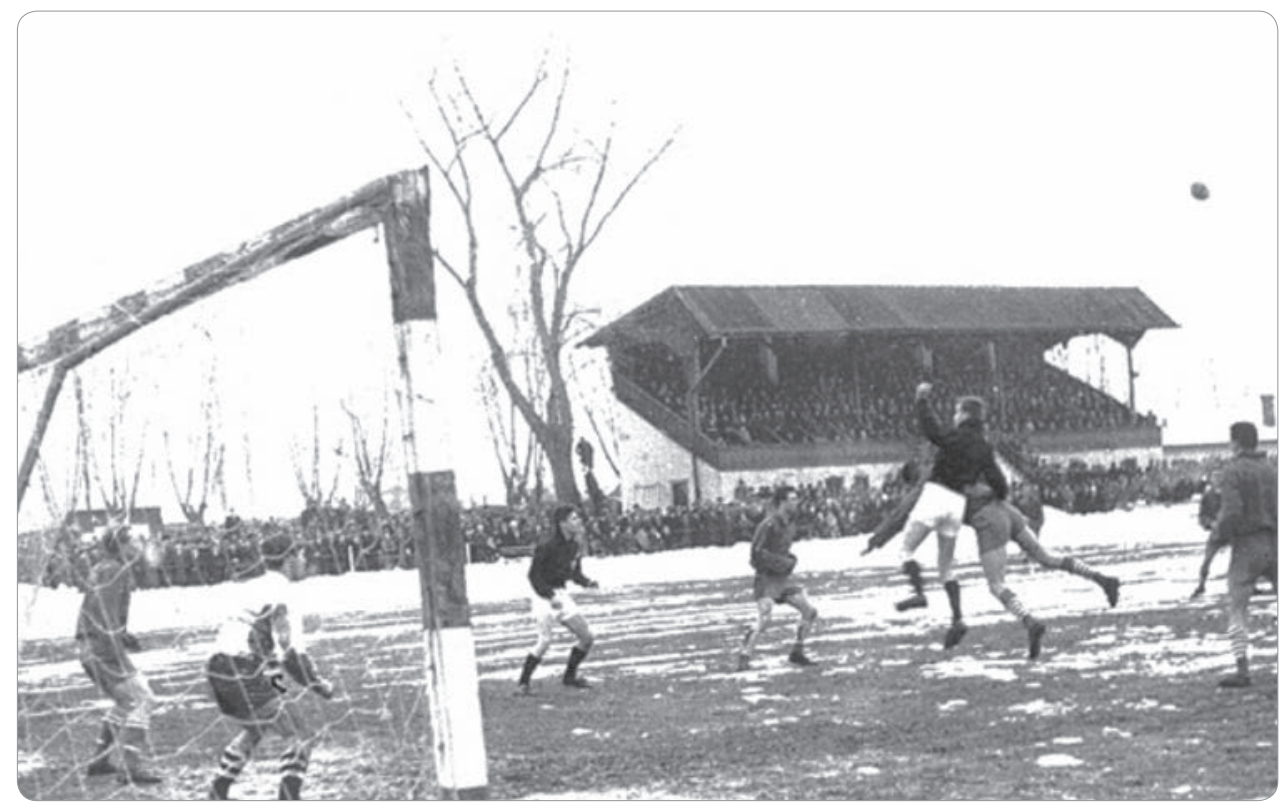

5. kép. DEAC-Kecskeméti Dózsa 4:1 (1962)

Az 1960-as évek csapatából:

1. Dr. Móricz Sándor középhátvéd Utánpótlás válogatott (1963) Bp. Honvéd (1962-1964)

Pécsi Dózsa (1964-1969)

2. Dr. Kassai László kapus Debreceni VSC (1963-1964)

3. Varsányi Antal szélsőhátvéd Debreceni VSC (1962-1964)
4. Dr. Kéki Miklós csatár Debreceni VSC (1963-1964)

5. Temesvári Tibor szélsőhátvéd Debreceni VSC (1963-1964) Ózdi Kohász (1964-1966)

6. Dr. Heindrich Gábor védő Ifúsági válogatott (1963) Szegedi EOL (1974) 
Az 1970-es évek csapataiból:

1. Kiss László csatár, középpályás

Salgótarjáni TC (1978-1980)

2. Gottdiener Sándor csatár

Békéscsaba (1977)

3. Dr. Bencze Sándor csatár

Ifúsági válogatott (1966-1967)

Tatabánya (1966-1968)

A DEAC-hoz került 1968-ban

4. Dr. Tóth József csatár

Egri Dózsa (1967)

A DEAC-hoz került 1968-ban

\section{A bemutatott korszak edzöi}

A DEAC bármilyen edzőjének, sportvezetőjének lenni szakmai rangot, társadalmi elismerést jelentett és jelent ma is.

Edzők: Kántor Dezső, Szarvas Albert (1953); Szarvas Albert (1954); dr. Thomas Henrik (1955); Szarvas Albert (1956); dr. Thomas Henrik, Palotás István (1957); dr. Thomas Henrik, Szarvas Albert (1957/58), őszi-tavaszi bajnoki rendszer; Szarvas Albert (1958/59, 1959/60); Szilárd Elek (1960 július-1962 december); Csende Sándor (1963 január-1964); Szilárd Elek (1965); dr. Bódor Lajos (1966-1972); Juhász Gyula (1972/73); Nagy Mihály (1973-75).

Szarvas Albert 1953-tól megszakításokkal mintegy fél évtizedig irányította a csapat szakmai munkáját. Jól együttműködött a szakosztály tagjaival, vezetőivel. Jó pedagógiai érzékkel megtalálta a közös hangot a játékosokkal, ügyesen építette be az együttesbe az új labdarúgókat. Vezetésével az NB III-ban hatodik (1957/58), harmadik (1958/59) és második (1959/60) helyezést is elért az alakulat.

Szilárd Elek 1960 júliusától 1962 decemberéig edzette, vezette a DEAC csapatát. $\mathrm{Az}$ egyetemi együtteshez kerülése előtt több Hajdú-Bihar megyei és debreceni csapatnál tevékenykedett. 1957-ben például az NB III-as Püspökladánynál.

Játékos múltja, szakmai hozzáértése, társaságkedvelő modora, egyéni humora, jó kapcsolatteremtő képessége révén rövid idő alatt széles körben nagy elismertségre és népszerüségre tett szert.

Idős kora ellenére jól bánt a labdával. Bemutatta, hogyan lehet a tizenhatos vonaláról 10 próbálkozásból nyolcszor eltalálni labdával a kapufát. Gyakran kikérte - még 
a taktikát és az összeállítást illetőleg is - a szakosztályvezetés és az idősebb játékosok véleményét, azt többnyire figyelembe is vette, de a döntés jogát fenntartotta magának. A szakosztályvezetés segítségével szakszerủen és jó érzékkel készítette fel a csapatot technikailag, taktikailag, erőnlétileg és lélektanilag egyaránt. Különösen mestere volt a lélektani ráhatásnak. Felismerte az egyes labdarúgók tehetségét, egyéni adottságait, és fejlesztette azokat. Mintegy két és fél évig egymást érték a már korábban felsorolt nagyszerü eredmények.

1962 őszétől a csapat teljesítménye visszaesett.

Az idény közepén, az 1963 januárjában végrehajtott edzőcsere nem oldotta meg a gondokat. A csapat Csende Sándor és a szakosztályvezetés minden igyekezete ellenére kiesett.

1965-ben újra szerződtették Szilárd Eleket. Az NB III-as bajnokságban tizedik, az országos főiskolai labdarúgó-bajnokságban újra első lett az együttes. 1966-tól dr. Bódor Lajos hétéves edzői időszaka következett.

Csende Sándor fiatal korában az NB III-as D. Kinizsiben futballozott sokoldalú, képzett középpályásként. Végzettsége szerint testnevelő tanár. 1963 januárjától júliusig a DEAC NB II-es csapatának edzője. A kiesés után az őszi félfordulós NB III-as bajnokságban vezetésével a második helyen végzett az együttes. 1965-ben a Nádudvar mestere. 1966-67-ben Kuba egyik tartományának labdarúgó sportigazgatója. Egy időben a DMVSC edzője, dr. Lakat Károly vezetőedző mellett. Hosszú ideig a Debreceni Sportiskola szakágvezetője. Válogatott labdarúgók nevelésében volt döntő szerepe. Például Sándor Tamás (11), Dombi Tibor (35), Boőr Zoltán (21)

37 évig dolgozott az egyetem testnevelési tanszékén, hosszabb ideig tanszékvezetőként (KLTE). 21 évig töltötte be a megyei labdarúgó szövetség elnöki tisztségét. 20 évig volt a DEAC ügyvezető elnöke. 2008-ban kapta meg a Magyar Labdarúgásért Érdemérem arany fokozatát.

A nemrég elhunyt dr. Bódor Lajos közel tíz éven keresztül a labdarúgó-szakosztály nagyon felkészült és rendkívül eredményes edzője és sportvezetője volt. Szinte második szülőként kísérte figyelemmel labdarúgói tanulmányi előmenetelét, pályáját. 1966-tól három évig az NB III-as együttes szakmai munkáját irányította. 1969-ben a csapat 4 pont előnnyel bajnokságot nyert, bekerült a másodosztályba, és ott sikeresen helytállt 4 és fél éven keresztül. Edzői munkája során sokan segítették szakmai tevékenységét, de a sikeres szereplés elsősorban az ő alapos, hozzáértő szakedzői tevékenységének volt köszönhető. 1972-től, betegségéből való felgyógyulása után több évig szakosztályvezetőként dolgozott.

Orvosi hivatását sem hanyagolta el. Klinikai belgyógyászként, körzeti orvosként, a Kenézy-kórház foorvosaként, kerületi ellenőrző föorvosként végezte feladatait, gyógyított nagyon eredményesen. 


\section{Sportvezetök, nélkülözhetetlen segitök}

Kiemelkedően fontos szerepet töltött be a szakosztály történetében dr. Szilágyi Tibor (1921-2007), a kórélettan professzora, az orvostudomány doktora, az immunológia, az allergológia, az ürbiológia nemzetközi szakértője. Az utánozhatatlanul sajátos modorú, jó humorú, hallatlanul közkedvelt és tisztelt professzor a legsikeresebb időszakokban, a bajnokságok megnyerése és a másodosztályú szereplések idején volt a labdarúgó szakosztály elnöke. 1973-74-ben a sportköri elnöki tisztet is betöltötte.

A szakosztályvezetés tagjai közül szinte senkit sem vett körül akkora megbecsülés és szeretet - főleg a játékosok, de mások részéről is - szakértelme, pozitív emberi tulajdonságai miatt, mint Balázs Sándort (1927-1991). 1955-től majd másfél évtizedig szakosztályvezetőként, intézőként és más tisztségekben is szinte atyai körültekintéssel szervezte, segítette, intézte a csapat, a játékosok ügyeit, dolgait. Történelem-földrajz szakos középiskolai tanárként szerzett diplomát.

Egy ideig az egyetemen tanársegédként dolgozott, de onnan 1956-os tevékenysége miatt elbocsátották. Tanári pályafutása során később sem önszántából változtatott gyakran munkahelyet. Végül a Fazekas Gimnáziumban talált megnyugvást, onnan is ment nyugdíjba.

Dr. Iglói Endre (1924-2001) orosz-szláv irodalmár, egyetemi tanár, tanárképzési rektorhelyettes, BTK dékán, többek között 1968-ban szakosztályi elnökként, később más módon is segítette, támogatta a csapatot.

Dr. Karmazsin László (1927-2012) gyermekgyógyász, egyetemi tanár, rektorhelyettes, majd rektor, fiatal egyetemi oktató korában, az 1955-ös évben intézőként, később más eszközökkel is sokat tett az egyetemi labdarúgásért.

Dr. Csicsai József 1953-ban szakosztályvezetői tagként, 1954-ben szakosztályvezetőként dolgozott odaadóan a labdarúgó közösségért.

Dr. Csorba Sándor kezdetben mint klinikai tanársegéd, később mint magas rangú egyetemi oktató 1959-től 1963-ig látta el nagyon lelkesen és szakszerủen a szakosztályvezetői feladatokat.

Dr. Thomas Henrik ügyvéd, egyetemistaként a DEAC hálóját őrizte. Egy időben a Kelet-magyarországi Labdarúgó-alszövetség (KLASZ) fötitkára volt. Az 1950-es, 60-as években a megyei szövetség egyik népszerű vezetőjeként szervezte a megyék közti NB III-as felnőtt és ifjúsági válogatottak találkozóit. 1957-58-ban az egyetemi csapat trénere, 1971-72-ben szaktanácsadója, 1972-73-ban szakosztályvezetője. Rövid ideig a DVSC szakmai munkáját is irányította, és ott intézőként is munkálkodott.

Dr. Kormos Miklós mint orvosegyetemista az 1960-as években szakszerűen, tárgyilagosan tudósított a DEAC mérkőzéseiről, az egyesület híreiről a Hajdú-bihari Naplóban és az Egyetemi Életben. Később különböző vezetői tisztségeket töltött be a labdarúgó-szakosztályban. Volt intéző (1968), szakosztályvezető (1971/72), időnként a vezetőség tagja. 


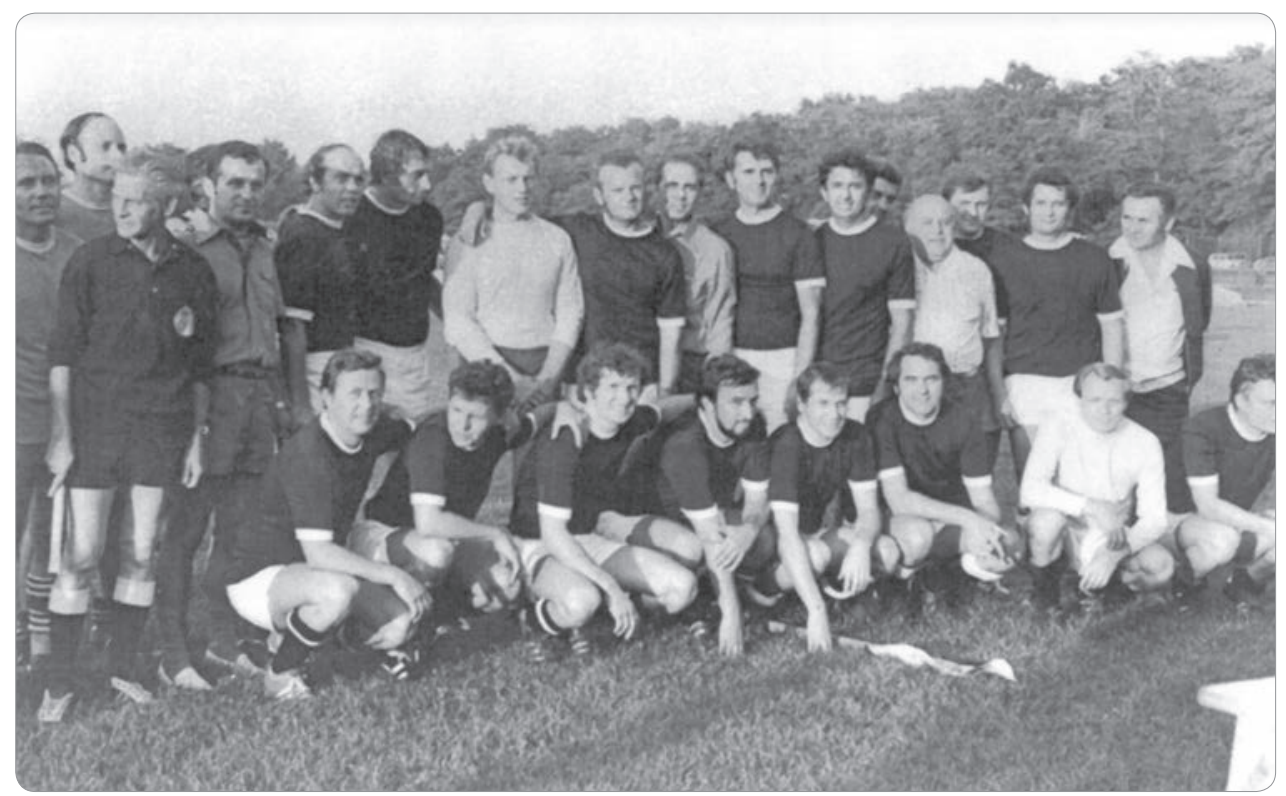

6. kép. Öregfuik mérközés (1974)

Jelentős szerepet játszott a DUSE létrejöttében és vezetésében.

37 évig csapatorvosi feladatokat látott el különböző korosztályú és sportágú csapatoknál, mindenki nagyfokú megelégedésére. Csapatorvosa volt többek között a labdarúgó „A”, az ifúsági, az utánpótlás és a női válogatottnak. Mint kiváló orvos kezelte, gyógyította az Aranycsapat játékosait, Grosics Gyulát, Puskást, Hidegkútit és Buzánszkyt. Évtizedekig vezette a Budapesti Szent János Kórház Kardio- és Pulmonológiai Osztályát.

Dr. Sója Szabolcs orvostanhallgató korában és még három évig a DEAC krónikása, sporttudósítója, időnként egyik szakvezetője. Frissen végzett orvosként 1965-ben, Londonban, Matthews búcsúmérkőzésén, a Nemzetközi válogatott - Stoke City mérkőzésen (6:4) megszerezte Puskás, Kubala, Masopust, Matthews és más labdarúgó hírességek aláírását.

Az egyetem befejezése után három évig klinikai orvos és tanársegéd Debrecenben.

Közel ötven éve Tállyán nagyon elismert háziorvosként, üzemorvosként, belgyógyászként praktizál, betegei legnagyobb örömére. Kimagasló orvosszakmai teljesítményét 2012-ben életmüdíjjal ismerték el. Több mint 10 évig volt a tállyai sportkör elnöke. 1976-ban a Testnevelési Főiskolán szakedzői képesítést szerzett. Tizenöt évig a megyei első osztályú tállyai labdarúgó együttes sikeres vezetőedzője. Hosszú ideig jelentős közéleti tevékenységet is végzett, mint a Borsod-Abaúj-Zemplén Megyei Közgyülés társadalmi megbízatású alelnöke. A DEAC archív dokumentumainak szorgalmas gyűjtője, az időskori sporttalálkozók egyik áldozatkész segítője. 
Loós Gyula, a szenvedélyes mestervadász, az elismert tanár és nyugdíjas iskolaigazgató 1959-től, egyetemista korától fényképekkel, sporttudósításokkal dokumentálta egyetemi társai, barátai futballpályákon bemutatott produkcióit. Jó szokását több mint 50 évvel később felelevenítette és a 2009-től szervezett időskori nosztalgia-találkozók eseményeit ma is önzetlenül, profi színvonalon örökíti meg.

\section{Egyetemi vezetök, oktatók, egyetemisták kapcsolata a DEAC-cal}

Mindkét egyetemen viszonylag népszerủ volt a testedzés, a versenysport, különösen a labdarúgás.

A fiatal egyetemi oktatók közül sokan és gyakran, a vezetők közül néhányan és időközönként, a hallgatók közül nagyon sokan és rendszeresen kilátogattak az egyetemi sporteseményekre, főleg a labdarúgó-mérkőzésekre.

Jó néhány egyetemi oktató tisztséget, feladatot is vállalt a sportegyesület vezetőségében, szakosztályaiban. Az egyetemi tanárok, oktatók azért is szívesen látogatták a mérkőzéseket, mert a lelátókon a légkör, a hangulat kellemes, szellemes, kulturált volt, valamint a labdarúgók egy része a legjobb tanítványaik közé tartozott.

A korabeli meghívó tanúsága szerint a labdarúgó-szakosztály újjáalakulásának 30 éves jubileuma alkalmából az 1977-ben szervezett megemlékezés, találkozó és örökifjak mérkőzés védnökei a következők voltak: dr. Kesztyüs Lóránt akadémikus, dr. Kónya István, a KLTE volt rektora, dr. Kulin László nyugdíjas egyetemi tanár, dr. Ökrös Sándor nyugdíjas egyetemi tanár, dr. Szabó Gábor, a DOTE volt rektora, dr. Törő Imre akadémikus.

A fentieken kívül a sportot, a labdarúgást, a mindenkori csapatot támogató, segíto", szponzoráló egyetemi vezetők, oktatók, szimpatizánsok alábbi névsora nagyon jelentős, de korántsem teljes.

Dr. Rapcsák András (1914-1993) matematikus, egyetemi tanár, rektor, akadémikus;

Dr. Albert Béla (1925-2006), a szemészet egyetemi professzora;

Dr. Szilágyi Tibor (1921-2007) egyetemi tanár;

Dr. Iglói Endre (1924-2001) egyetemi tanár, BTK dékán;

Dr. Karmazsin László (1927-2012) gyermekgyógyász, egyetemi professzor, rektor;

Dr. Csaba Béla, az immunológia, a kórélettan professzora;

Dr. Endes Pongrác (1907-1992), a DOTE nagy tekintélyü tanszékvezető profeszszora megértő, de nagyon szigorú vizsgáztató hírében állt. Egy alkalommal még a saját fiát is, a fiú szerint is jogosan, utóvizsgára kötelezte. Szigorúsága ellenére, egyebek mellett nagy tudása és sportszeretete miatt rendkívül népszerű volt, különösen a labdarúgó orvos-egyetemisták körében. 
Dr. Orosz István az idén 83 éves. Történészprofesszorként, dékánként, oktatási rektorhelyettesként, akadémikusként, a Debreceni Egyetem története 1912-2012 című alapmü föszerkesztőjeként, 2008-tól Debrecen díszpolgáraként írta be nevét az egyetem, a város történetébe. Professzor úr fiatal egyetemi oktató korában és később is nagy barátja volt a sportnak, a labdarúgásnak. Hatalmas szaktudása, barátságos, közvetlen modora, segítőkészsége okán nagyon sok egyetemi hallgató, köztük történelem szakos labdarúgók is őt választották szakdolgozatuk témavezetőjének.

Dr. Jakab László, nyugdíjas docens, mindannyiunk örömére ma is jó egészségnek örvend. Aktív tanár korában magyar nyelvészetet tanított az egyetemen. Tanár úr nem csak a DEAC, de a DVSC mérkőzéseit is gyakran látogatta. Fiatal korában maga is kiváló atléta, jó nevű sprinter volt. A politika, a sport, a labdarúgás aktuális eseményeiről tartott élményszerű elemzései, utánozhatatlan egyéniségéből, sajátosan lenyűgöző stílusából fakadóan eseményszámba mentek az egyetemi hallgatók körében.

\section{Az 1960-as évek néhány játékosának vázlatos sportolói és szakmai pályafutása}

Dr. Kassai László (1936-1990) személyiségét leginkább a tudatosság, a rendkívüli akaraterő, a győzni akarás, az erős koncentráló képesség, a kitartás és a szorgalom jellemezte. Kitűnő kapusadottságokkal rendelkezett. Csapatkapitányként a pályán és a pályán kívül is összetartó, jó szellemű, értékorientált közösséget tudott teremteni.

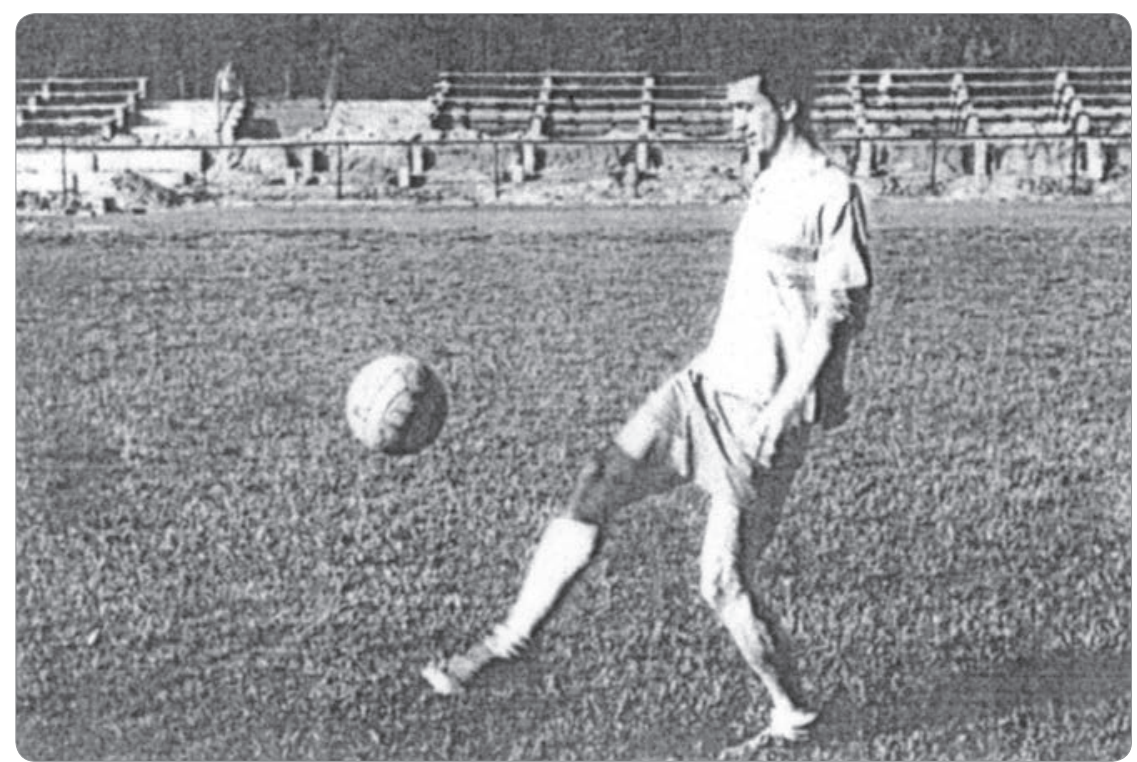

7.kép. Szegedi Gyula edzésben (1954) 
1956 és 1963 között a DEAC kapuját védte. Másfél évig az NB I-es DVSC hálóját őrizte, 1965-ben rövid időre visszatért anyaegyesületébe. Döntő szerepe volt az NB III-as és az NB II-es egyetemi csapat minden sikerében. A kapuban bravúrt bravúrra halmozott. A DVSC-ben is átlagon felül teljesített, sokszor volt a csapat legjobbja.

Diplomájának 1961-es megszerzése után az Ortopédiai Klinika, majd a Kórélettani Intézet orvosa. 1964-től volt egyetemi tanársegéd. Laboratóriumi szakvizsgát tett. Lakásgondjai miatt Pápára költözött, ahol a kórház laboratóriumi fóorvosa lett. Az ajkai kórházban megszervezte a laboratórium beindítását, valamint a vérellátó osztályt is vezette. 1976-tól haláláig Miskolcon, a Megyei Kórházban laboratóriumi osztályvezető föorvos, megyei szakföorvos volt. 1984-től címzetes egyetemi docens. Közel 70 tanulmányt írt, és 200 tudományos előadást tartott. Rendkívül ígéretes orvosszakmai karrierjének folytatását sajnálatosan korai halála törte ketté.

Dr. Szegedi Gyula (1936-2013), 1954-től több mint tíz évig meghatározó játékosa volt az egyetemi csapatnak, többnyire középcsatárként, de játszott középhátvédet is. 1960-ban NB III-as gólkirály volt. Tizenhatszor szerepelt az NB III-as megyeválogatottban. Döntő része volt az együttes hírnevének, elismertségének megalapozásában, az 1961-es NB III-as bajnokság megnyerésében és a kétéves NB II-es jó szereplésben is.

1962-ben avatták népköztársasági aranygyürűs orvosdoktorrá. 1965-ben belgyógyászatból tett szakvizsgát. 1971-ben védte meg kandidátusi disszertációját. 1975-ben egyetemi tanári kinevezést kapott. Vezetése alatt a III-as számú Belgyógyászati Klinika az immunológia országos központjává vált. 1990-ben szerezte meg az orvostudomány doktora fokozatot. 1979 és 1985 között a DOTE oktatási, 1995 és 1999 között pedig a klinikai rektorhelyettesi teendőket látta el. 2001-ben az Akadémia rendes tagjává választották. Jelentős tudománypolitikai és társadalmi tevékenységet végzett. Kiváló munkásságát számos magas kitüntetéssel ismerték el, többek között a Magyar Köztársasági Érdemrend tisztikeresztjével és Széchenyi-díjjal. 2000-től lett szülővárosa, Újszász díszpolgára.

Temesvári Miklós 1957 és 1963 között volt az NB III-as és az NB II-es egyetemi csapat középpályás kulcsjátékosa. 1960-ban főiskolai bajnok. 1963-tól hat évig az NB I/B-s Miskolci VSC egyik legfontosabb labdarúgója. Kiváló taktikai érzéke, játékának kreativitása, támadó játékfelfogása, lelkesedése nagy értéke volt mindenkori együttesének. 1962-ben kapta meg a magyar-angol szakos tanári diplomáját. Néhány évig neves debreceni és miskolci gimnáziumokban tanított, majd a futballedzői pályát választotta.

Az NB I-es Nyíregyháza, az Újpesti Dózsa, a Tatabánya, a DVSC és a Diósgyőr vezetőedzőjeként ezüstérmet, bronzérmet, kétszer kupagyőzelmet ért el. Az Újpesti Dózsát 1983/84-ben a Kupagyőztesek Európa-kupájában a legjobb nyolc közé juttatta. A Maldív-szigetek szövetségi kapitányaként csapatával a Dél-Ázsiai Játékokon 1991ben a második, 1993-ban a harmadik helyet szerezte meg. Sikereket ért el kuwaiti, szudáni és albániai sportklubbokban is. Több mint 25 országban vezetett továbbképzéseket a FIFA instruktoraként. Hosszú ideig az MLSZ edzőbizottsága elnökeként tevékenykedett, 2010-ben kapta meg a mesteredzői címet. 
Egyedülálló sporttörténeti gyüjteménnyel rendelkezik.

A régi DEAC labdarúgók találkozóinak fő szorgalmazója, szervezője, szereplője. Jellegzetes humora, lenyügöző egyedi stílusa, sajátos egyénisége sokakat bámulatba ejt.

Valamennyi volt DEAC-játékos közül dr. Móricz Sándor labdarúgó pályafutása volt a legsikeresebb. 1958-tól 1962-ig az együttes középhátvédjeként kimagasló szerepet játszott a bajnokság megnyerésében és az NB II-es sikerekben. 1962-től a Budapesti Honvéd sportolója, ahol az Aranycsapat harminchétszeres válogatott középhátvédje, Lóránt Gyula az edzője. 1963-ban utánpótlás válogatott. 1964 és 1969 között a Pécsi Dózsa kihagyhatatlan alapembere. NB I-es mérkőzéseinek száma 160. Sokszor volt a forduló válogatottja Alberttal, Fazekassal, Benével együtt. 1969-ben bekerült „A bajnoki év válogatottja” B csapatába. Ebben az évben az NB I-es játékosok abszolút rangsorában 250 labdarúgó közül az 5. helyet szerezte meg.

Egyetemi tanulmányait Pécsett fejezte be. Sebész szakorvosi képesítést szerzett. Hosszú ideig a pécsi Megyei Kórház Sebészeti Oktató Tanszékén adjunktusként tevékenykedett, de ellátott traumatológiai és aneszteziológiai feladatokat is. Bonyhádon a sebészeti szakrendelés föorvosaként is dolgozott.

Varsányi Antal (1936-2012) 1957-től hat évig a DEAC, majd az élvonalbeli DVSC hátvédje. A DVSC első osztályból való kiesése után hosszú ideig tovább játszott az NB I/B-s és az NB II-es együttesben is. Valamennyi csapatában alapvetően meghatározó szerepet töltött be. Abszolút megbízható, jól képzett, kétlábas, kiváló rúgótechnikájú védőjátékos volt. Nagyon jól rúgta a szabadrúgásokat és a tizenegyeseket is.

Az NB I-es DVSC-ben többnyire sikerrel vette fel a harcot például Sándor Csikarral, Alberttal, Tichyvel is. 1964 augusztusában az MTK ellen (2:1) a Népstadion kettős mérkőzésén Kéki doktorral együtt 50 ezer néző elött futballoztak. A szerény, szimpatikus labdarúgó, röntgentechnikusi szakmájában is a legjobbak közé tartozott.

1957-től 1963-ig az egyetemi csapat szurkolói, majd másfél évig az NB I-es Debreceni VSC hívei, 1965 őszétől 1969-ig ismét a DEAC szimpatizánsai élvezhették, időnként csodálhatták dr. Kéki Miklós (1938-2007) magas szintű technikai képzettségét, mozgásának atlétikusságát, harmóniáját, cselezőkészségét, gólerősségét.

1963-as diplomaszerzése után az egyetem röntgen részlegén klinikai orvos. 1971-től a Győr-Sopron Megyei Kórház I-es Számú Radiológiai Osztályának szakorvosa. 1976-tól négy évig Nigériában dolgozott, ahol a radiológiai munka mellett egy új kórház beindítása és két új röntgenosztály munkájának megszervezése is feladata volt. Hazaérkezése után a központi radiológiai osztály osztályvezető föorvosa lett, valamint elindította az angiográfiás diagnosztikai vizsgálatokat és a mammográfiát az intézményben. Emellett ellátta a megyei szakföorvosi feladatokat is. Tapasztalatszerzés céljából többször járt külföldi intézetekben, például Japánban és Kanadában is. Kimagasló orvosi tevékenységét a város, a szakma, az intézmény több magas kitüntetéssel jutalmazta.

Közel egy évtizedig elképzelhetetlen volt az NB III-as és az NB II-es egyetemi labdarúgó közösség dr. Szücs János kemény, lelkes, csupaszív, gólerős csatár, majd középhátvéd játéka nélkül. Többször volt NB III-as megyeválogatott, sok emlékezetes 


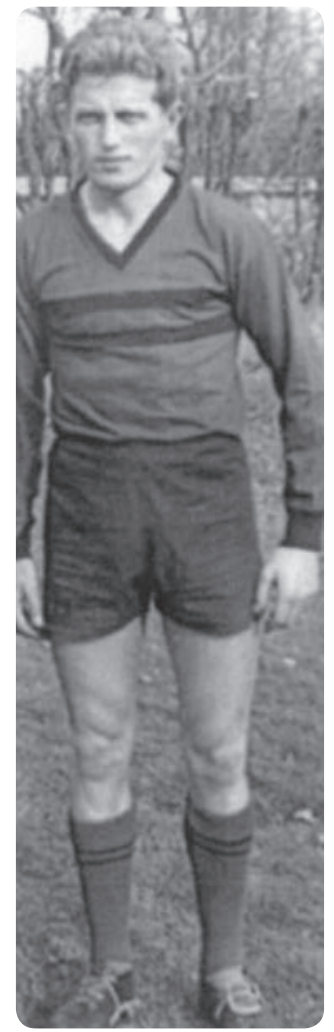

8. kép. Az NB I-es

DVSC-ben is játszó Kéki Miklós

gól szerzője. Kitűnően szerepelt Kassai doktorral, Környeivel, Móriczcal együtt 1962 márciusában a szovjet B válogatott Debrecen válogatott mérkőzésen (3:2), ahol gólpasszt adott és gólt is szerzett.

Mint szakosztályvezető jelentős szerepet játszott az 1969-es bajnokcsapat és az NB II-es együttes sikereiben. Klinikai egyetemi adjunktusként kiemelkedő szakmai és tudományos eredményeket ért el, tanítványai rajongtak érte. Kiválóan operált. Hosszú ideig a Berettyóújfalui Kórház fül-orr-gége osztályának osztályvezető föorvosaként dolgozott.

Dr. Cséfalvai Ignác 1957 és 1963 között volt az egyetemi alakulat alapembere, balfedezete, védekező középpályása, de ha kellett, megállta a helyét más posztokon is. Játékának döntő elemeit a megbízhatóság, a higgadtság, a legteljesebb kétlábasság, a váratlan súlypontáthelyezés, a sportszerüség adták. Játéka Zakariáséra emlékeztetett. Magyar-történelem szakos középiskolai tanári oklevele után jogi diplomát is szerzett.

Évtizedekig a Szegedi Tudományegyetem Tanulmányi Osztályának vezetőjeként, valamint az egyetem kollégiumának igazgatójaként tevékenykedett. Címzetes főiskolai docensként rendkívül népszerủ volt a hallgatók körében. A Mérnöki Karon közel 50 évig gazdasági főigazgató-helyettesként dolgozott. Énekhangja, zenei képzettsége hivatásos művészekével vetekszik.

Stefanik György 1958-tól 1963-ig tartozott az NB III-es és az NB II-es DEAC labdarúgó közösségébe. A kezdetben kőkemény jobbhátvédből ugyancsak kőkemény, viharosan gyors, sodró lendületű, kapura veszélyes, kihagyhatatlan jobbszélső lett. Egyetemre kerülése előtt tagja volt a magyar ifiválogatott keretének. A DEAC után Gyula NB II-es csapatának egyik kulcsjátékosa.

Magyar-történelem szakosként végzett. Gyulán kollégiumi igazgatóként és szakközépiskolai tanárként tevékenykedett. A diákok közkedvelt, kollégái felkészült, elismert tanárként tartották számon. Kedvelte a társaságot. Széles baráti körrel rendelkezett. Tragikusan korai halála mély részvétet keltett.

A balszélső Filetóth László sok fontos győztes gól szerzője. Elévülhetetlen érdemeket szerzett az 1961-es bajnokság megnyerésében és az eredményes NB II-es szereplésben. Kétszeres főiskolai bajnok $(1960,1965)$. Öccse, Filetóth János az 1970-es években csatárként erősítette a DEAC csapatát.

Filetóth László 1965 és 1967 között az NB I/B-s Miskolci VSC kulcsjátékosa, majd két évig a Kazincbarcikai Vegyész NB II-es együttesének leggólképesebb csatára. 1969ben a Nemzeti Bajnokság második osztályának abszolút gólkirálya 34 találatával. Vegyészként 35 évig a Sajóbábonyi Vegyiművek dolgozója üzemmérnöki, üzemvezetői, 
gyárrészlegvezetői beosztásban. 78 éves korában is kispályás labdarúgó mérkőzések aktív résztvevője.

Dr. Környei László 1957-től az együttes kirobbanthatatlan, nagyon kemény jobbhátvédje. Az akkoriban még nagyon ritka, felfutó, támadó védőként futballozott.

Középiskolai tanári oklevelének átvétele után doktori címet szerzett. Mintegy két évtizeden keresztül Miskolc város Művelődésügyi Osztályának szigorú vezetője, a közoktatás és a művelődésügy nagyon elismert szakembere. Jelentős szerepe volt a település művészeti életének fejlesztésében is. Középiskolai igazgatóként fejezte be szakmai karrierjét. Máig nagy rajongója és elismert szakértője a képzőművészetnek, a képgyűjteményeknek.

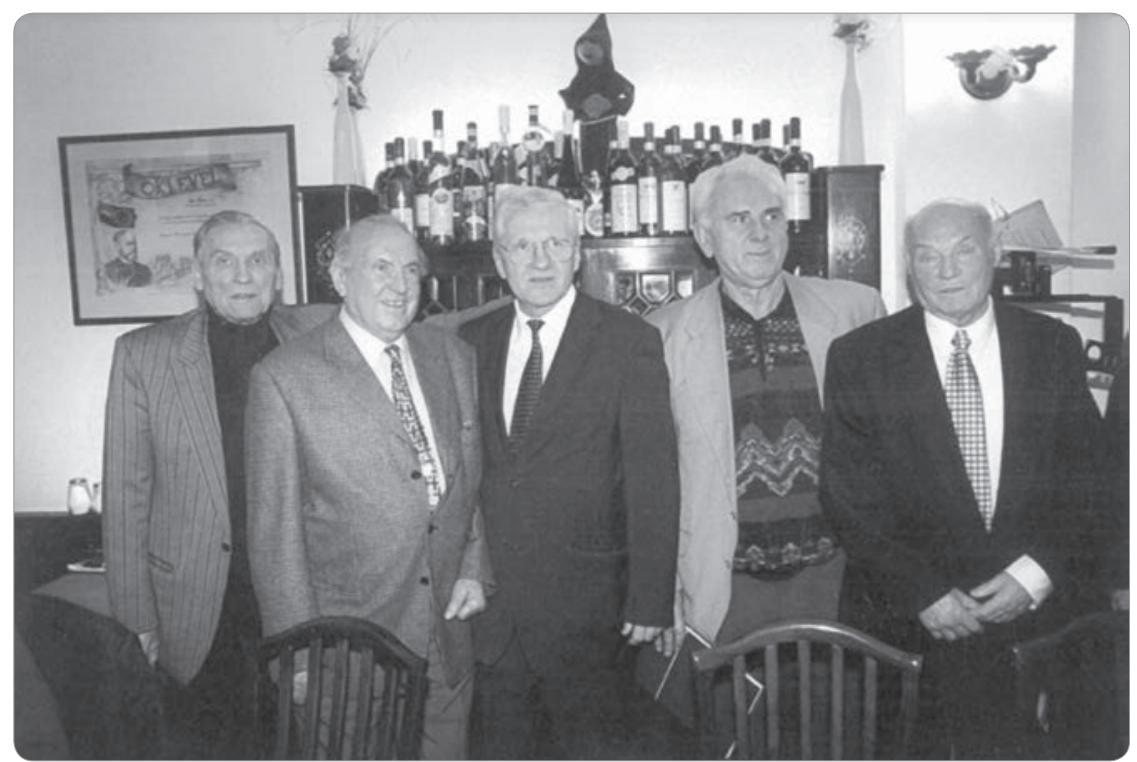

9. kép. Az Aranycsapat tagjai egykori DEAC-os orvosaikkal:

Grosics Gyula, Hidegkúti Nándor, dr. Veress Gábor, dr. Kormos Miklós, Buzánszky Jenö

Dr. Veress Gábor 1962 nyarától 5 évig a klub történetének egyik leggólerősebb csatára. Gyors volt, nagyon lelkes, néha önveszélyesen is vakmerő. Kitűnően fejelt és cselezett. 1962-ben a huszadik másodpercben rúgott győztes gólt Debrecenben az NB II-es Budapesti Spartacusnak. 1965-ben az országos főiskolai labdarúgó-bajnokság döntőjében ő szerezte meg az aranyérmet jelentő győztes találatot. Az Újpesti Dózsa elleni kupamérkőzésen gólpasszt adott Polák Zoltánnak, valamint a második hazai gólt ő maga szerezte (2:4). 1968-ban az NB II-es DVSC, majd az NB I/B-s Kecskeméti Dózsa játékosa lett.

Dr. Veress Gábor orvosként belgyógyász, kardiológus, az orvostudományok kandidátusa, egyetemi magántanár. 1996-tól a Balatonfüredi Állami Szívkórház főigazgató föorvosa. Több hazai és külföldi tudományos orvostársaság tagja, tisztségviselője. Széles 
körủ tudományos és oktatói tevékenységet folytat. Jelentős hazai és nemzetközi kongresszusok, valamint külföldi tanulmányutak, továbbképzések résztvevője és szervezője.

Több magas kitüntetés tulajdonosa, Balatonfüred díszpolgára (2009). Országos és nemzetközi szenior teniszversenyeken egyéniben és párosban több első és dobogós helyezést ért el. Orvosként kezelte, gyógyította az Aranycsapat játékosait. Alkalmi énekesként, zongoristaként, zenészként ma is lenyügözi közönségét.

Temesvári Tibor 1959 és 1963 között a harmad- és másodosztályú DEAC, 1963/64-ben az NB I-es DVSC, 1964-66-ban a szintén első osztályú Ózdi Kohász lelkes, a csapatért, a labdarúgásért mindent megtevő védőjátékosa volt. Legnagyobb sikereit Ózdon aratta. Életében a labdarúgás foglalta el a központi helyet. Később négy NB I/B-s csapatban is játszott.

1964-ben kapott bölcsészdiplomát. Sikeres labdarúgó pályafutásának befejezése után szakedzői képesítéssel nyugdíjazásáig különböző csapatoknál vezetőedzőként egzisztált. Edzette többek között az NB III-as Tiszavasvárit, az NB II-es Jászberényt, a Veszprémet, a Bajai SK-t, az Ózdi Kohászt.

Dr. Dévai László 1961 júliusától 1966-ig középpályásként és csatárként állt az egyesület rendelkezésére. Kombinatív játékfelfogásával, tért ölelő pontos indításaival, rendkívül fejlett periférikus látásával sokszor hozta helyzetbe játékostársait. Két évig az NB II-es, majd az NB III-as együttes egyik legfontosabb futballistája. Tagja volt az 1965-ös föiskolai bajnokcsapatnak is.

Mint sebész és mint traumatológiai szakorvos nyolc évig a miskolci Megyei Kórház baleseti sebészetén, 25 évig a MÁV Rendelőintézetben dolgozott. Hosszú évekig anyaegyesülete, a Miskolci MTE sportorvosi teendőit is ellátta.

Várhelyi Gusztáv nagyon képzett, sokoldalú labdarúgó volt. Az összjátékhoz való érzéke, futballszeretete több poszton is átlagon felüli teljesítményre tették képessé. Öt évig volt tagja az egyesületnek. 1965-ben aranyérmet szerzett a föiskolai bajnokcsapat védőjeként. Később az NB I/B-s DVSC, majd a Szolnoki MTE, végül az NB II-es Kazincbarcikai Vegyész igazolta le. Vegyészként később szakmérnöki diplomát is szerzett. 30 évig, elhunytáig, Szolnokon a Közép-Tiszavidéki Vízügyi Igazgatóságon különböző vezetői beosztásokban tevékenykedett.

Buglyó Tibor 1962 júliusától öt évig legtöbbször támadó középpályásként, gyakran csatárként bizonyította tehetségét. Kiváló rúgótechnikája és nagy lövőereje következtében a távolról lőtt gólok mestere volt. Vegyészként kapott diplomát. Korai haláláig a NYÍRSÉG Konzervipari Vállalat termelési igazgatói posztját töltötte be.

Dr. Mályi Imre labdarúgó balösszekötőként, balfedezetként és balhátvédként nyújtott nagyon elismert, jó teljesítményt. Az 1960-as föiskolai bajnokegyüttes és az 1961es bajnokcsapat tagja. Az NB II-es alakulatban mutatott egyre érettebb játékát, ígéretes labdarúgó pályafutását egy legrosszabbkor jött betegség szakította meg.

Elismert gasztroenterológus. A legmodernebb műtéti és szakmai eljárások kezdeményezője és bevezetője. Közismert újságírókat, sportolókat, színészeket, politikusokat 


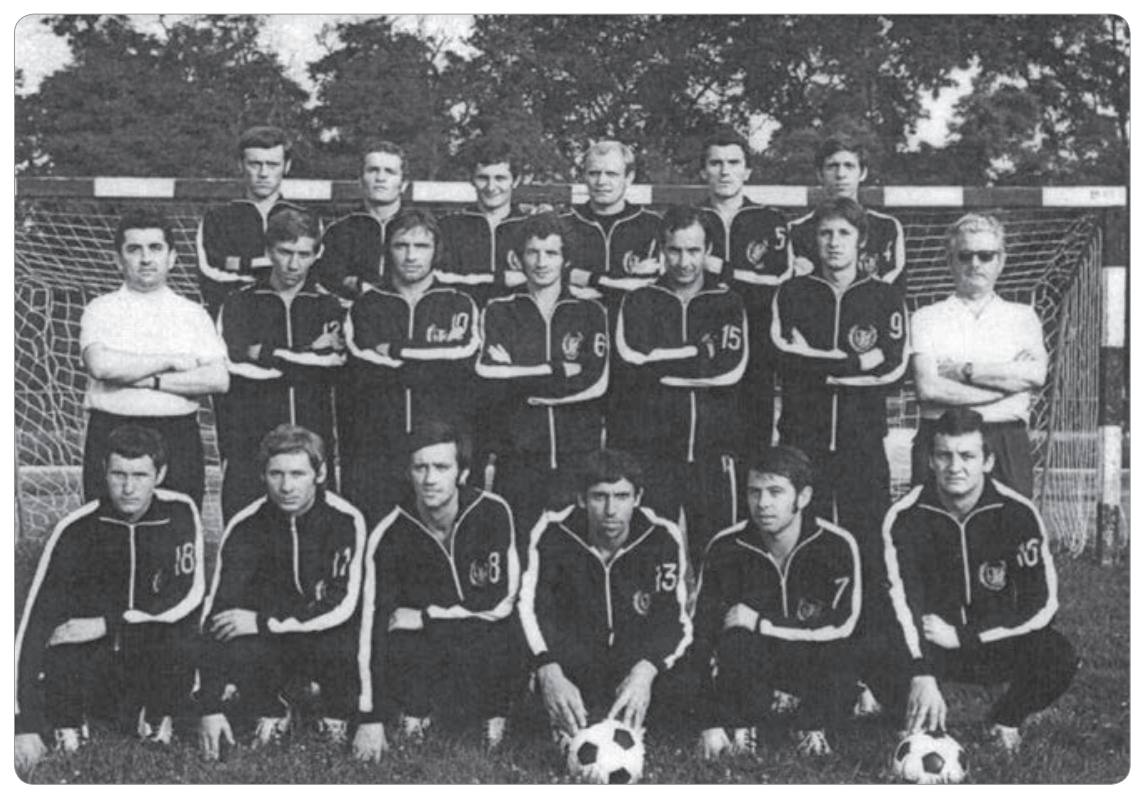

10. kép A DEAC 17 fós játékoskerete (1974)

kezelt, gyógyított. Több évtizedig dolgozott a BM Központi, valamint a Bajcsy-Zsilinszky Kórház osztályvezető főorvosaként. Munkáját számos kitüntetéssel ismerték el. Tizenhétszeres korosztályos országos orvos-teniszbajnok, egyszeres orvos-világbajnok (1995, Franciaország).

Dr. Heindrich Gábor 1963-tól 1968-ig volt az egyetemi gárda nagyszerű adottságokkal rendelkező, tehetséges, nagyon jól fejelő középhátvédje. Többszörös magyar ifjúsági válogatott. A magyar Nemzeti Bajnokság minden osztályában játszott. 1968ban az NB II-es DVSC, később az NB I/B-s Szolnoki MTE kulcsjátékosa. 1974-ben az élvonalbeli Szegedi EOL-ban fejezte be az aktív játékot. Itt a huszonötszörös magyar válogatott, Bundzsák Dezső volt az edzője, aki a magyar női labdarúgó-válogatottnak 19 mérkőzésén volt a szövetségi kapitánya.

1968-ban magyar-történelem szakos középiskolai tanári diplomát szerzett, 1979-ben elvégezte a jogi egyetemet is. Hét évig a Szegedi Városi Bíróság bírája, majd a Csongrád Megyei Bíróság elnöke. 2003-ban nevezték ki a Szegedi Ítélőtábla elnökévé. Neve felvetődött a legfőbb ügyész hivatalának betöltése idején is. Többek között a Köztársasági Érdemrend középkeresztje kitüntetés tulajdonosa.

A kiválóan lövő, kombinatív, gyors balszélső Polák Zoltán öt évig játszott a csapatban. Nyolc évig volt a miskolci Járási, majd a Városi Mủvelődésügyi Osztály munkatársa. 1984 és 1990 között Sajóbábony rendkívül népszerü tanácselnökeként irányította a települést. A kiváló pedagógiai és empatikus érzékkel rendelkező középiskolai tanár 27 évnyi tanítás után elismert, megbecsült miskolci pedagógusként vonult nyugdíjba. 
Lelkes, kiválóan szerelő, kemény, de mindig sportszerű, jó emberfogó szélsőhátvédként futballozott 1963 és 1967 között az egyetemi NB III-as csapatban Kenyeres Sándor. 1967-ben szerezte meg történelem-földrajz szakos diplomáját. Rendkívül hatékony és kreatív szaktanári, pedagógiai, vezetői és kultúraterjesztő tevékenységét elsősorban Gyöngyösön és környékén fejtette ki. Igazgatóhelyettesként, kollégiumi és szakközépiskolai igazgatóként eredményes, értékorientált, összetartó pedagógiai, nevelői közösséget tudott teremteni. Profi szintű amatőr gyümölcs-, szőlö- és bortermelő.

\section{Portrévázlatok az 1970-es évek játékosairól}

Az 1969 és 1975 közötti egyetemi labdarúgó közösség elképzelhetetlen volt dr. Csapó Kálmán megbízható, egyenletes, sallangmentes, lelkes, irányító középhátvéd játéka nélkül. Meghatározó ember volt az 1969-es NB III-as bajnokság megnyerésében, és a négy és fél éves sikeres NB II-es szereplésben. A szezonvégi edzői-szakosztályi értékelések legtöbbször a legjobbak között említik. Többször játszott a korosztályos magyar UEFA együttesben, később a föiskolai válogatottban.

Az általános orvosi diplomát „summa cum laude” minősítéssel szerezte meg. Öt évig Debrecenben klinikai orvos, majd egyetemi tanársegéd. Néhány év alatt belgyógyászati, kardiológiai és tüdőgyógyászati szakorvosi szakvizsgát tett. Közben vezette a Kardiológiai és az Intenzívosztályt. 1990 és 2004 között a Kardiológiai Klinika egyetemi adjunktusa. 1999-ben szerzett PhD-fokozatot. 2000 és 2005 között Debrecenben, majd Miskolcon, a Megyei Kórházban a hemodinamikai laboratórium vezetését látta el. 2008-tól nyugdíjba vonulásáig a miskolci kórházban a Bel- és a Kardiológiai Osztály osztályvezető föorvosa. Több hazai és külföldi orvosi szakmai társaság tagja, tisztségviselője. Számos elismerés, kitüntetés tulajdonosa, többek között a BatthyányStrattmann László-díj kitüntetettje (2013).

Kiss László az 1960-as évek végétől 1974-ig az NB III-as, majd az NB II-es együttes kiemelkedő képességű csatára. A szurkolók leginkább nagyszerű cseleire, kombinációs érzékére és góljaira emlékeznek.

1974 és 1978 között az NB II-es DVSC-t erősítette. Ezután 2 évig az NB I-es Salgótarján középpályása. Negyvenkét bajnoki mérkőzésen vett részt, hat gólt szerzett. Többször volt a forduló válogatottja. Edzője dr. Lakat Károly, tizenháromszoros magyar válogatott, hatszoros szövetségi kapitány. Tokióban és Mexikóvárosban az aranyérmes olimpiai csapat szakvezetője. Magyar-történelem szakos középiskolai tanári képesítést szerzett. Újságíróként a Nógrád, a Népsport, a Mai nap, a Blikk vezető munkatársa, labdarúgó szakírója volt. Jelenleg a Magyar Hírlap többszörösen kitüntetett lapszerkesztője, sportrovat vezetője. Önálló szépirodalmi kötete is megjelent.

Dr. Puskás László 16 évig volt a DEAC igazolt labdarúgója. A serdülő, az ifúsági és a felnőtt csapatban is játszott. Az 1969-ben bajnokságot nyert gárda és a négy és fél 
évig NB II-es együttes egyik nélkülözhetetlen futballistája. Szigorú hátvédként és veszélyes csatárként egyaránt lehetett rá számítani. Édesapja, idősebb Puskás László, nagyon hosszú ideig a DEAC, rövid ideig a DVSC labdarúgó szakosztályának vezetőségében tevékenykedett.

Ifjabb Puskás László több mint 36 éve Göncön mindmáig elismert, megbecsült háziorvosként praktizál. 20 évig hozzáértő, eredményes szakvezetője volt a gönci megyei első osztályú csapatnak. Szabadidejében szívesen vadászik. A DEAC történetének és hagyományainak egyik legfőbb ápolója. Segíti és önzetlenül támogatja a labdarúgó szakosztály történetének feldolgozását, a régi játékosok találkozóit.

Rendkívül megbízható, ugyanakkor bravúrokra is képes kapusa volt a csapatnak Pálchuber Károly, aki 1968 és 1972 között állt a klub rendelkezésére. Hosszú ideig a csapatkapitányi feladatokat is ellátta. 1969-ben az NB III teljes mezőnyének legjobb kapusteljesítményét nyújtotta, de nagyszerüen helytállt az NB II-es bajnokságban is. Orosz-lengyel-francia szakon végzett. Mint az orosz és a lengyel nyelv tanításának országos szakértője nagy tekintélyre tett szert a szakmában. Tanítványai kimagasló eredményeket értek el az országos középiskolai tanulmányi versenyeken. Egy időben a senior teniszversenyeken szerzett pontjai a világranglista 42. helyét biztosították számára. Több kiváló játékos, sportvezető életpályájának, sporttevékenységének méltatása terjedelmi okokból nem került be az összeállitásba. Tölük elnézést és megértést kérünk.

\section{Felhasznált irodalom}

- A Debreceni Egyetem története 1912-2012, szerk. Orosz István-ifj. BarTa János, Debrecen, 2012.

- SÁndor Mihály, A debreceni futball képes kalauza, Debrecen, 2010.

- Hegri Iván, Labdarúgó VB könyv 1930-2010, Debrecen, 2010.

- Berkő Péter, Miskolci orvosok a betegek és a tudomány szolgálatában, Miskolc, 2016.

- Miskolci Életrajzi Lexikon, szerk. Dobrossy István-Eszenyi Miklós-ZachuczKy László, Miskolc, 2008.

- BerÉnYI István, Dr. Veress Gábor Balatonfüred város díszpolgára, Balatonfüred, 2010.

- A Hajdú-bihari Napló, az Egyetemi Élet és a Népsport korabeli számai (1957. február 26-1974. december 4.).

- DUSE Hiradó: https://www.magyarfutball.hu/en/csapat/386

- A szerzö magángyüjteménye (2008), 212 lap.

- Régi DEAC-labdarúgók magángyüjteményei. 